\title{
Mineralogical study of archaeological copper slags found in the area of Krushevets Village, SE Bulgaria
}

\author{
Nikoleta Tzankova ${ }^{1}$, Dobrinka Stavrakeva² \\ ${ }^{1}$ Department of Mineralogy and Petrography, University of Mining and Geology "St Ivan Rilski”, 1700 Sofia, Bulgaria; \\ e-mail:niktzankova@abv.bg \\ ${ }^{2}$ University of Chemical Technology and Metallurgy, 8 Kl.Ohridsky Blvd, 1756 Sofia, Bulgaria, \\ e-mail:dobrinka@uctm.edu
}

(Accepted in revised form: June, 2020)

\begin{abstract}
In this article, we present the results of our study on archaeological slags found near the village of Krushevets, Southeast Bulgaria. Chemical analyses of the slags show a high $\mathrm{Fe}_{2} \mathrm{O}_{3}(40.11-54.57 \%)$ and $\mathrm{SiO}_{2}$ (29.32-42.28\%) content, increased $\mathrm{CaO}$ content (3.01-6.51\%), as well as very low quantity of $\mathrm{SO}_{3}$ (from $0.20 \%$ to $0.52 \%$ ) and $\mathrm{P}_{2} \mathrm{O}_{5}$ (between $0.23 \%$ and $0.30 \%$ ). The unbound residual copper in the samples is in an amount of $0.41 \%$ to $1.07 \%$. The main phases composition of the slags are as follows: fayalite-type silicate phases with impurities, kirschsteinite and laihunite; pyroxenes of the augite-type and amorphous hosted glass; iron-oxide phases (magnetite and maghemite); and copper-containing phases (drops of unbound copper, relicts of ore minerals such as bornite, chalcopyrite), as well as newly formed phases, such as chalcocite, and copper-containing spherical aggregates. The studied samples are a by-product of copper extraction metallurgical activity. The raw material used was of copper-sulfide type with impurities of manganese-, calcium-, magnesium- and aluminium-containing minerals.
\end{abstract}

Tzankova, N., Stavrakieva, D. 2020. Mineralogical study of archaeological copper slags found in the area of Krushevets Village, SE Bulgaria. Geologica Balcanica 49 (2), 3-23.

Keywords: Archaeological copper slags, SEM CDD-EDS, X-ray powder diffraction, old copper mining, SE Bulgaria.

\section{INTRODUCTION}

The formation of copper ore deposits in the Burgas ore region is closely connected to four Late Cretaceous volcano-plutonic centers - Rosen, Varli Bryag, Zidarovo and Bakadzik. They were grouped in the four ore fields of the same names (Fig. 1). Three subformation types were subdividied among them: vein copper-molybdenium (Rosen), vein copper (Varli Bryag) and vein copper-polymetallic (Zidarovo and Bakadzik) (Bogdanov, 1987).

This paper presents the results of study on byproducts from metallurgical activity, found in the Zidarovo ore field. It is located south of the Varli Bryag and west of the Rosen ore fields (Fig. 1). The copper-gold-polymetallic mineralizations in the Zidarovo ore field are of hydrothermal origin. The copper ore deposits named Kanarata and Yurta are of the greatest industrial importance (Bogdanov, 1987).
The studied slags were found in a locality named Bakarbokluk (copper trash in Bulgarian), situated southwest of the village of Krushevets, Sozopol Municipality. Georgiev (1987, pp. 38-39) and Mihaylov (2010) mentioned the presence of old mine excavations in the area. During the recent research there (Leshtakov et al., 2015), ceramic fragments were found and, in addition, slags were also collected. The ceramic fragments date the studied metal mining activity back to the Hellenistic and Late Antiquity (Leshtakov et al., 2015). Our field study did not lead to the finding of ore mineralization near the slag. The closest mineralization is Karaissak (unpublished study of Kalin Ruskov) with chalcopyrite, malachite, azurite and limonite, which is located about $1300 \mathrm{~m}$ to the west-southwest of the village of Varshilo (Hristov et al., 1953) and is attached to the contact zone around the Harmanski (Varshilski) Pluton. 


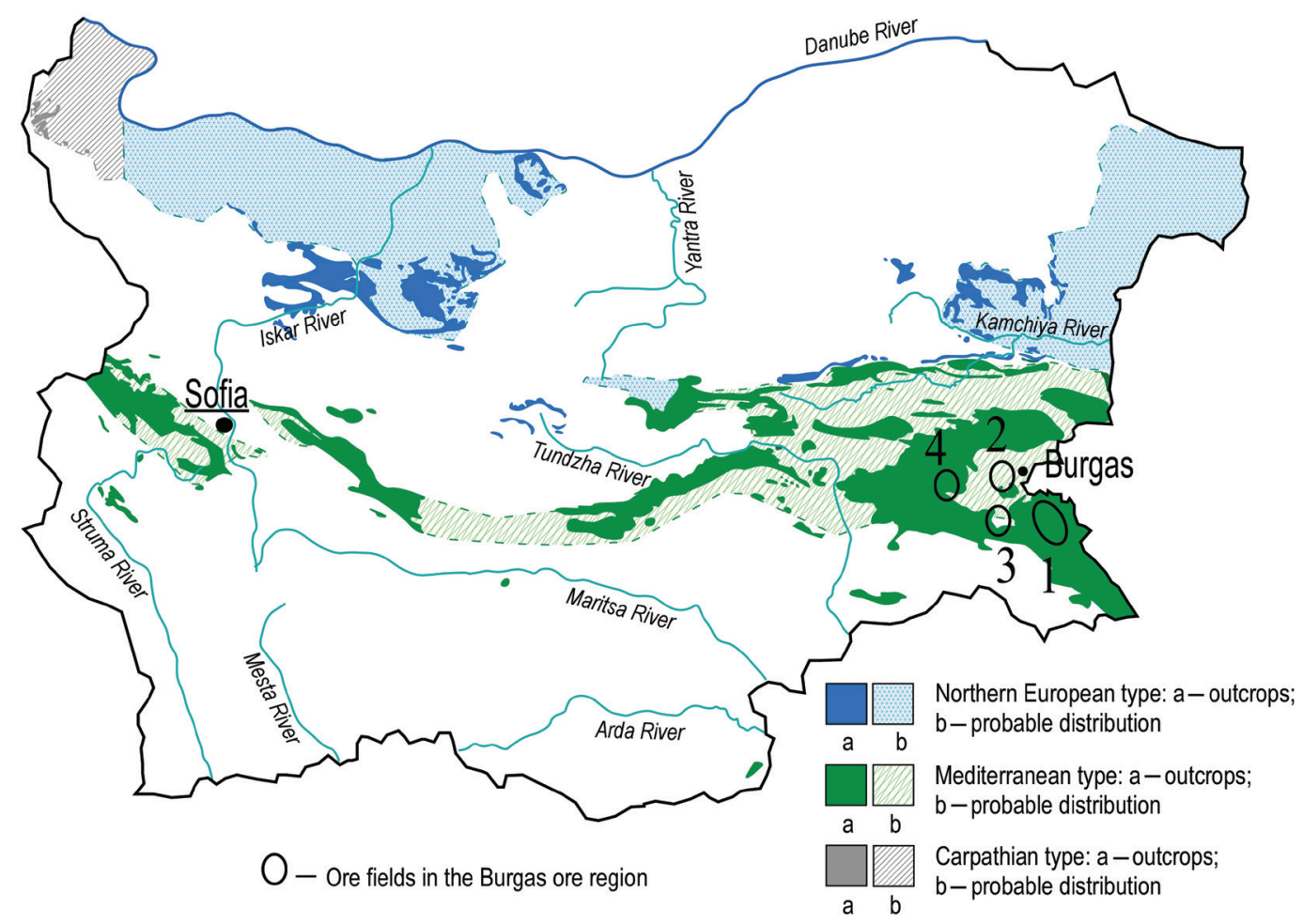

Fig. 1. Outcrop and subcrop occurrences of Upper Cretaceous rocks in Bulgaria (after Dabovski, 2009) and locations of copper ore fields in the Burgas ore region: 1) Rosen; 2) Varly Bryag; 3) Zidarovo; 4) Bakadzhik (according to Bogdanov, 1987, and Milev et al., 1996).

The purpose of this study is to obtain data about the chemical and mineralogical peculiarities of the slags from Krushevets. These data will clarify the type of metal extracted and also the characteristics of the ore used. This research is a part of a complex study on archaeological slags from the Burgas and Yambol ore regions (Stavrakeva and Tzankova, 2016a, 2016 b; Tzankova et al., 2016).

\section{MATERIALS AND METHODOLOGY}

\section{Materials}

The object of this study is more than 70 slag samples with a dark grey, almost black colour on a freshly broken surface. A common feature of the studied slags is the presence of a number of different secondary phases resulting from weathering. We observed secondary phases of dark green to yellow green, pink, rusty, red and white colours on the slag surfaces, occurring as coatings or stains. Some of them fill slag pores. The secondary phases are usually represented by carbonates with green color, orange-red iron oxides and hydroxides (Fig. 2). According to specimen colour and number of pores, we divided the analysed samples into three groups: 1a, 2 and 3a. Each of the groups 1a and 3a were subdivided into two subgroups:

1) group 1a $\left(1 a^{1}\right.$ and $\left.1 a^{2}\right)$ - grey, almost black slag, with visible crystal prismatic phases on a freshly broken surface, non-magnetic. The pores are up to $5 \mathrm{~mm}$ in size, visible only on the specimens' surfaces (Fig. 2a). Samples from group $1 \mathrm{a}^{2}$ contain a greater number of crystal phases visible to the naked eye than the slags from group $1 \mathrm{a}^{1}$;

2) group 2 - slags are grey-green, non-magnetic, heavy and compact, with microscopic pores (Fig. 2b);

3) group $3 a\left(3 a^{1}\right.$ and $\left.3 a^{2}\right)$ - these slags are grey to reddish, with magnetic properties. The samples from group $3 \mathrm{a}^{1}$ (Fig. $2 c$ ) are coarse-grained and relatively dense. They contain fewer pores than samples from group $3 \mathrm{a}^{2}$ (Fig. $2 d$ ). The size of the pores is usually about $1-2 \mathrm{~mm}$, rarely up to $8-9 \mathrm{~mm}$. The smaller amount of pores in the samples from group $3 \mathrm{a}^{1}$ indicates their slower cooling.

\section{Methodology}

The powdered and homogenized in an agate mortar slag samples were prepared for Powder X-ray dif- 

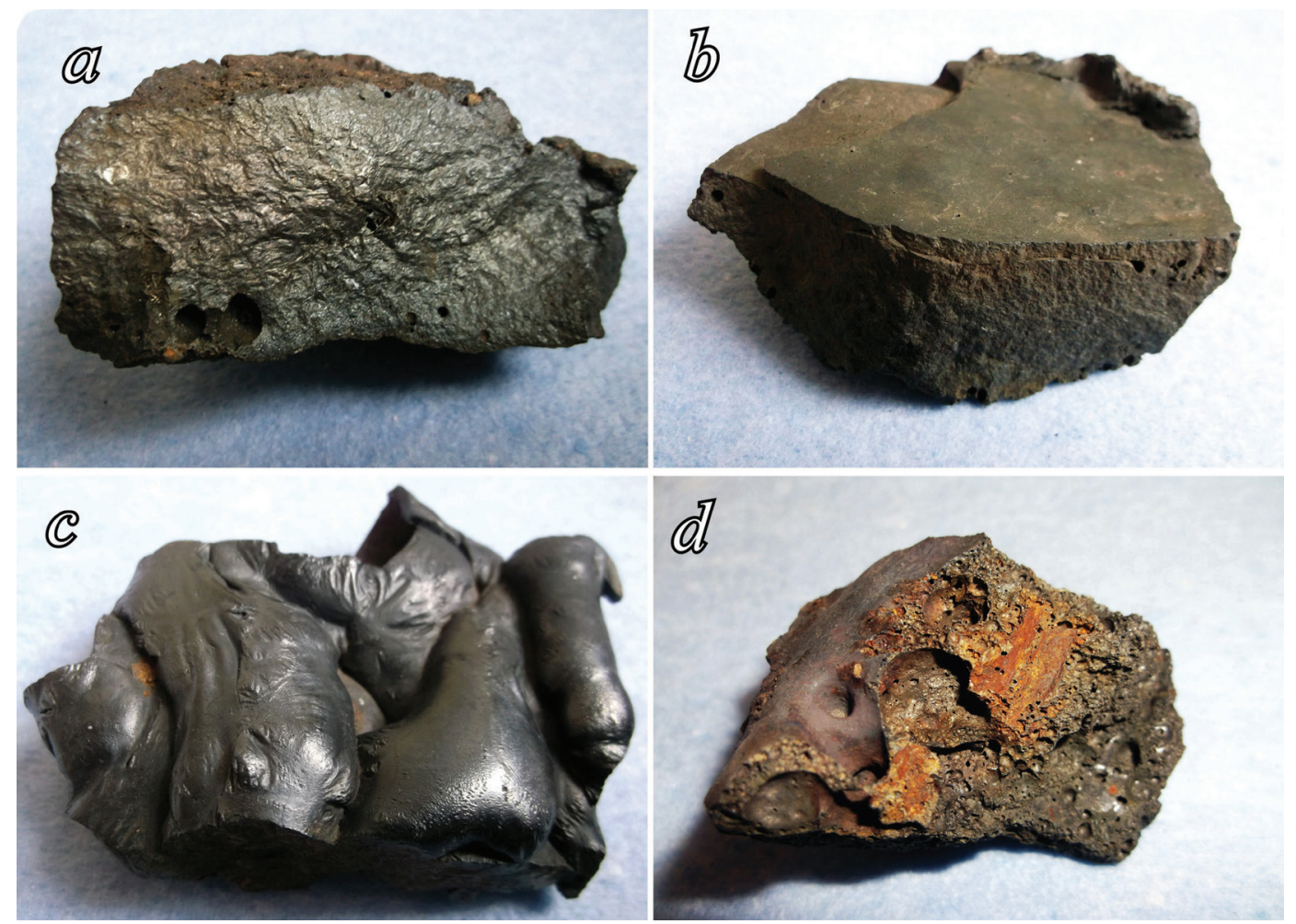

Fig. 2. Macroscopic photographs of the slags selected for this study: $a$ ) sample from group 1a with crystalline prismatic phases on its surface, $8.5 \times 3.5 \times 3.5 \mathrm{~cm} ; b$ ) sample from group 2 with grey-green colour, $8 \times 7 \times 3 \mathrm{~cm} ; c$ ) sample from group $3 \mathrm{a}^{1}$ with very little pore content, $7 \times 5 \times 1.5 \mathrm{~cm}$; d) sample from group $3 \mathrm{a}^{2}$ with weathering crust of orange-red iron oxides, $5 \times 3.5 \times 2.5 \mathrm{~cm}$.

fraction and subsequent ICP-OES analyses. XRD patterns for the selected samples were obtained, using a Bruker D2 Phaser X-ray diffractometer (at $30 \mathrm{kV}$ and $10 \mathrm{~mA}$, with $\mathrm{CuK} \alpha$ radiation, $2 \theta$ range from $4^{\circ}$ to $70^{\circ}, 0.2 / 0.5 \mathrm{~s}$ ). The JCPDS PDF database (International Centre for Difraction Data, 1997) was used for data interpretation. The bulk chemical composition of the slags was examined with inductively coupled plasma: optical emission spectrometry 720-ICP-OES, Agilent Technologies. The preliminary optical studies on the polished samples and thin-sections were carried out, using optical microscopes Meiji MT9200 and MT9430 in transmitted and reflected light mode. The microstructure of the samples and chemical composition of the slag phases were studied with JOEL JSM 6010 Plus/LA InTouchScope $^{\mathrm{TM}}$ Scanning Electron Microscope (SEM) equipped with a silicon drift detector energy dispersive X-ray spectrometer (SDD-EDS) with a resolution of $128 \mathrm{eV}$. The device is equipped with a software platform that ensures accuracy and precision of measurements, and produces useful concentration values of the measured elements (Newbury and Ritchie, 2013). SEM CDD-EDS microanalyses were performed on highly polished flat specimens with graphite coating, $20 \mathrm{kV}$ accelerating voltage. All analyses were conducted at the University of Mining and Geology "St Ivan Rilski” (Sofia, Bulgaria). The content ratio of basic oxides ( $\mathrm{CaO}$ and $\mathrm{MgO})$ to acidic oxides $\left(\mathrm{SiO}_{2}\right.$ and $\left.\mathrm{Al}_{2} \mathrm{O}_{3}\right)$ was used for assessment of the basicity of slag (B). The calculation of the valence of transitional elements in the composition of crystal phases is according to the methodology proposed by Stavrakeva (1990).

\section{RESULTS}

\section{Bulk composition of the slags}

The studied slags are mainly composed of $\mathrm{SiO}_{2}$ (29.32-42.28\%), $\mathrm{Fe}_{2} \mathrm{O}_{3}$ (40.11-54.57\%), $\mathrm{CaO}(3.01-$ 6.51\%) and $\mathrm{Al}_{2} \mathrm{O}_{3}$ (7.01-9.03\%) (Table 1). Slags with such type of composition are often referred to as fayalite slags, as fayalite often precipitates from these slags on cooling. The slag samples are relatively similar in their chemical composition. In addition, the studied slags also contain minute amount of $\mathrm{TiO}_{2}, \mathrm{MgO}, \mathrm{MnO}, \mathrm{K}_{2} \mathrm{O}, \mathrm{Na}_{2} \mathrm{O}, \mathrm{P}_{2} \mathrm{O}_{5}, \mathrm{SO}_{3}$ and $\mathrm{Cu}$. The content ratio of basic oxides ( $\mathrm{CaO}$ and $\mathrm{MgO})$ to acidic oxides $\left(\mathrm{SiO}_{2}\right.$ and $\left.\mathrm{Al}_{2} \mathrm{O}_{3}\right)$ used for 
Table 1

Chemical composition of the studied archaeological slags obtained from ICP-OES analyses, basicity of slag (B)

\begin{tabular}{|c|c|c|c|c|}
\hline \multirow[t]{2}{*}{ Oxides } & \multicolumn{4}{|c|}{ Content, mass \% } \\
\hline & $\begin{array}{c}\text { Sample } \\
1 \mathrm{a}\end{array}$ & $\begin{array}{c}\text { Sample } \\
2\end{array}$ & $\begin{array}{c}\text { Sample } \\
3 a^{1}\end{array}$ & $\begin{array}{c}\text { Sample } \\
3 \mathrm{a}^{2}\end{array}$ \\
\hline $\mathrm{SiO}_{2}$ & 37.79 & 42.28 & 29.32 & 39.72 \\
\hline $\mathrm{TiO}_{2}$ & 0.28 & 0.32 & 0.21 & 0.30 \\
\hline $\mathrm{Al}_{2} \mathrm{O}_{3}$ & 9.03 & 7.17 & 7.77 & 7.01 \\
\hline $\mathrm{Fe}_{2} \mathrm{O}_{3}$ & 41.34 & 40.11 & 54.57 & 41.58 \\
\hline $\mathrm{CaO}$ & 5.98 & 5.56 & 3.01 & 6.51 \\
\hline $\mathrm{MgO}$ & 2.45 & 2.12 & 2.17 & 2.19 \\
\hline $\mathrm{MnO}$ & 1.05 & 0.25 & 0.72 & 0.15 \\
\hline $\mathrm{K}_{2} \mathrm{O}$ & 0.87 & 1.58 & 1.05 & 1.14 \\
\hline $\mathrm{Na}_{2} \mathrm{O}$ & 0.18 & 0.20 & $<0.05$ & 0.44 \\
\hline $\mathrm{P}_{2} \mathrm{O}_{5}$ & 0.27 & 0.30 & 0.23 & 0.26 \\
\hline $\mathrm{SO}_{3}$ & 0.32 & 0.46 & 0.20 & 0.56 \\
\hline $\mathrm{Cu}$ & 0.74 & 0.45 & 1.07 & 0.41 \\
\hline Moisture & 0.01 & 0.01 & 0.13 & 1.50 \\
\hline$\Sigma$ & 100.31 & 100.81 & 100.50 & 101.77 \\
\hline B & 0.18 & 0.16 & 0.14 & 0.19 \\
\hline
\end{tabular}

assessment of the basicity of slag is shown in Table 1 . If the basicity value is greater than one, the slag is referred to as basic; slag with a basicity value small- er than one is referred to as acidic. The basicity of all studied samples is less than 1 , which determines the slags as acidic. When acidic oxides melt, they form polyions which give acidic slags high viscosities, making them difficult to handle, and increasing the amount of entrained copper or matte. Basic slags have low viscosities and high solubilities for acidic oxides. Up to a certain limit, adding basic oxides lowers the melting point of a slag (Schlesinger et al., 2011).

\section{Mineralogy and phase composition of slag sample 1a}

\section{Powder XRD analysis}

This slag consists mainly of crystal phases from the olivine group, as indicated by XRD analysis. The dominant phase is fayalite $\mathrm{Fe}_{2} \mathrm{SiO}_{4}$ (Fig. 3, Fa). It is the most abundant phase composing this material, which was also confirmed by microscopic observations and elemental microanalyses. In addition to fayalite, magnesium fayalite $(\mathrm{Fe}, \mathrm{Mg})_{2} \mathrm{SiO}_{4}$ (olivine, $\mathrm{Ol}$ ) and kirschsteinite $\mathrm{CaFe}^{2+} \mathrm{SiO}_{4}$ (Kir) were detected in the sample, as well as augite-type pyroxene (Aug) (Fig. 3).

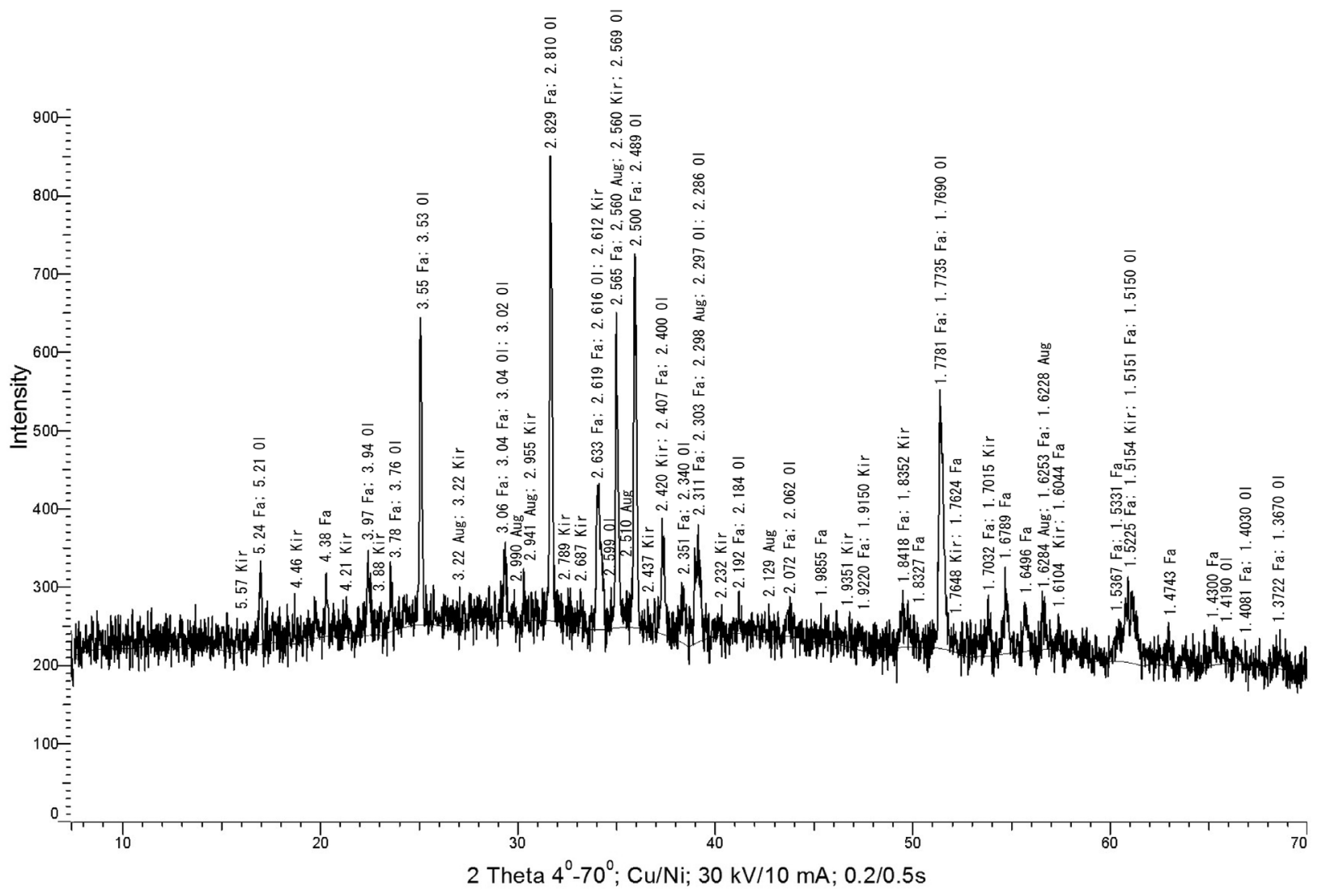

Fig. 3. XRD graph of sample 1a: fayalite (Fa); magnesium fayalite (olivine, Ol); kirschsteinite (Kir), augite (Aug). 

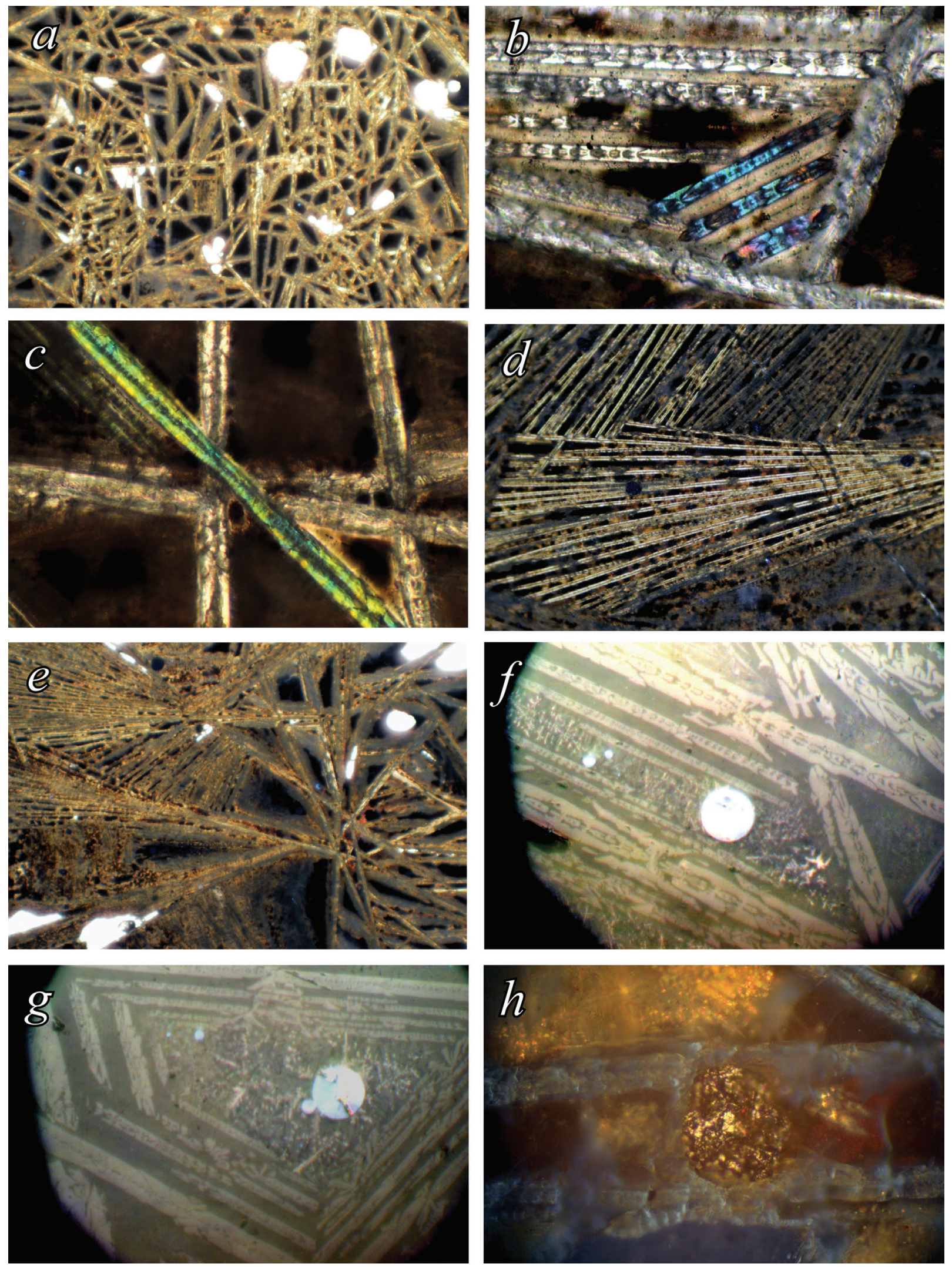

Fig. 4. Microstructure of slag sample $1 \mathrm{a}^{1}: a$ ) needle-like fayalite crystals, $\times 4$, plane-polarized transmitted light; $\left.b, c\right)$ skeletal and elongated fayalite crystals, $\times 40$, cross-polarized transmitted light; $d$ ) sub-radiating fayalite aggregates, $\times 10$, plane-polarized transmitted light; e) sub-radiating fayalite aggregates, $\times 4$, plane-polarized transmitted light; $f$ ) copper-sulfide aggregates, $\times 40$, plane-polarized reflected light; $g$ ) copper-sulfide aggregates, $\times 40$, plane-polarized reflected light; $h$ ) inhomogeneous copper-sulfide aggregates with relicts from the ore used, $\times 40$, plane-polarized reflected light. 


\section{Light optical microscopy}

Representative slag microstructure and phase assemblages, observed microscopically in transmitted and reflected light, are given in Figs 4, 5.

Sample $1 a^{1}$. Fayalite and silicate glass are the dominant silicate phases of the studied slag. Fayalite occurs as needle-like or prismatic skeletal crystals, indicating rapid crystallization (Fig. $4 a-c)$. These crystals either are randomly distributed in the matrix or form sub-radiating aggregates (Fig. $4 d, e$ ). According to data from the XRD study, fayalite-type crystal phases are represented by fayalite $\mathrm{Fe}_{2} \mathrm{SiO}_{4}$, magnesium fayalite and kirschsteinite $\mathrm{CaFe}^{2+} \mathrm{SiO}_{4}$ (Fig. 3). Fayalite crystals associate with elongated pyroxene crystals in the studied slags. The presence of augite-type pyroxene was also confirmed by the XRD and elemental microanalyses (Figs 3, 6b, c). The silicate matrix contains copper droplets and spherical inhomogeneous copper-sulfide aggregates. Most of them are scattered between the fayalite crystals (Fig. $4 f-h$ ). Microscopically, copper sulfide relics of the raw material used were observed in these aggregates (Fig. $4 h$ ).

Sample $1 a^{2}$. Microstructurally, this sample is analogous to sample $1 \mathrm{a}^{1}$. Fayalite crystals are skeletal and prismatic. Most of them form sub-radiating to parallel aggregates of prismatic crystals (Fig. 5a, b). Pyroxene crystals are small, needle-like, scattered among the fayalite ones.

Magnetite is in small amount. Under reflected light microscopy, it is light grey with brownish tinges and low reflectivity. Magnetite shows isotropic skeletal and dendritic forms, unevenly distributed in the volume of the sample, most often near sulfide inclusions. In this sample, in reflected light, there are many small copper droplets and copper-sulfide aggregates. Some of them have a distinct core and peripheral part (Fig. $5 c, d$ ).

\section{Silicate phases}

Silicate crystal phases in the studied sample are represented by fayalite, magnesium fayalite (olivine), laihunite, kirschsteinite and augite-type pyroxene. Variations in the chemical composition of the silicate crystal phases in samples $1 \mathrm{a}^{1}$ and $1 \mathrm{a}^{2}$, according to ten elemental microanalyses' (SEM CDD-EDS) data, are shown in Table 2. Fayalite, magnesium fayalite (olivine), kirschsteinite and pyroxene of augite type were detected by Powder XRD analysis with their characteristic set of d-spacings (Fig. 3).

The silicate phases in samples $1 \mathrm{a}^{1}$ and $1 \mathrm{a}^{2}$ are fayalite (Fa), laihunite (La), pyroxene (Py) and slag glass (Glass). Their representative chemical com-
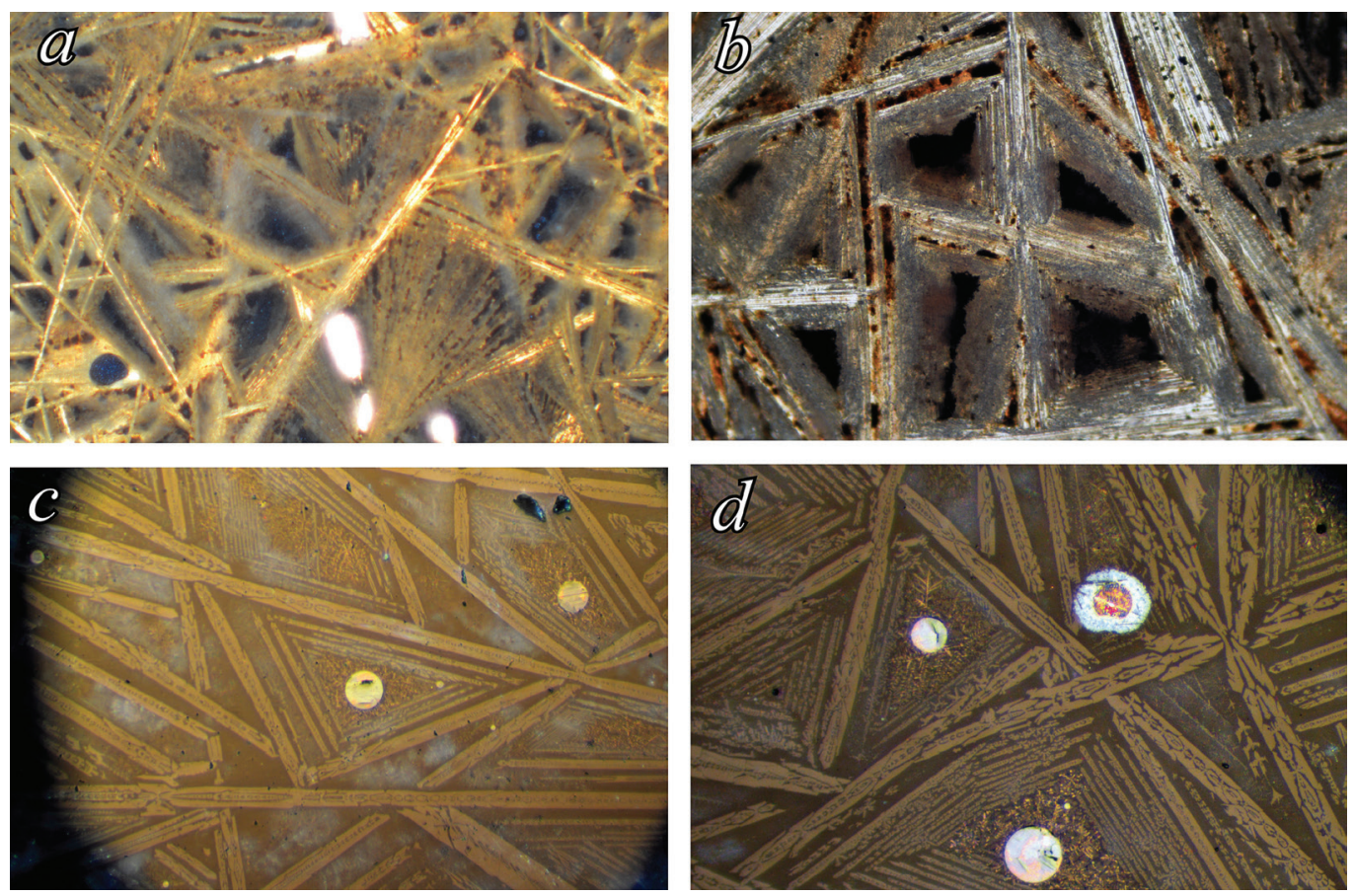

Fig. 5. Microstructure of slag sample $1 \mathrm{a}^{2}: a$ ) prismatic crystals and sub-radiating fayalite aggregates, $\times 4$, plane-polarized transmitted light; $b$ ) parallel aggregates of prismatic fayalite crystals, $\times 10$, plane-polarized transmitted light; $c$ ) copper droplets and coppersulfide aggregates, $\times 20$, plane-polarized reflected light; $d$ ) copper-sulfide aggregates and prismatic skeletal fayalite crystals, $\times 20$, plane-polarized reflected light. 
Table 2

Variations in the chemical composition of the silicate crystal phases in samples $1 a^{1}$ and $1 a^{2}$ according to data from elemental microanalyses (SEM CDD-EDS)

\begin{tabular}{lcc}
\hline & \multicolumn{2}{c}{ Content, mass \% } \\
\cline { 2 - 3 } Oxides & $\begin{array}{c}\text { Sample } 1 \mathrm{a}^{1} \\
\text { (calculated from } \\
4 \text { points) }\end{array}$ & $\begin{array}{c}\text { Sample } 1 \mathrm{a}^{2} \\
\text { (calculated from } \\
\text { 6 points) }\end{array}$ \\
\hline $\mathrm{FeO}$ & $59.29-62.77$ & $47.56-60.94$ \\
$\mathrm{MgO}$ & $4.38-4.74$ & $2.10-6.53$ \\
$\mathrm{CaO}$ & $0.66-1.45$ & $0.64-4.25$ \\
$\mathrm{MnO}$ & $1.82-2.14$ & $1.45-2.10$ \\
$\mathrm{Al}_{2} \mathrm{O}_{3}$ & $0-1.50$ & $0.83-5.72$ \\
$\mathrm{~K}_{2} \mathrm{O}$ & - & $0-0.79$ \\
\hline
\end{tabular}

positions are shown in Table 3. The major crystal phase in the studied materials is fayalite (Fig. $7 a$, $b$ ). The chemical composition of the silicate crystalline individuals in the analysed field $1 a^{2}-2$ (Fig. 7c) with a shape of parallel skeletal forms are chemically close to transient between fayalite $\left(\mathrm{Fe}_{2} \mathrm{SiO}_{4}\right)$ and laihunite $\left(\mathrm{Fe}_{1.6} \mathrm{SiO}_{4}\right)$. These phases include impurities of magnesium, calcium, manganese, some aluminium and potassium, which were introduced from the slag glass during faster crystallization.

The silicate phases presented in Table 3 have the following crystal chemical formulas:

In the analysed field $1 a^{1}-1$ (Fig. $6 a$ ):

- Point 1: $\left(\mathrm{Fe}_{1.72} \mathrm{Mg}_{0.23} \mathrm{Mn}_{0.05} \mathrm{Ca}_{0.02}\right)_{2.02} \mathrm{Si}_{0.99} \mathrm{O}_{4}-$ fayalite;
- Point 2: $\left(\mathrm{Fe}_{1.73} \mathrm{Mg}_{0.21} \mathrm{Mn}_{0.06} \mathrm{Ca}_{0.02}\right)_{2.02} \mathrm{Si}_{0.99} \mathrm{O}_{4}-$ fayalite;

In the analysed field $1 a^{1}-2$ (Fig. $6 b$ ):

- Point 8: $\left(\mathrm{Fe}_{1.06} \mathrm{Ca}_{0.52} \mathrm{Mg}_{0.06} \mathrm{Mn}_{0.05} \mathrm{~K}_{0.02} \mathrm{Na}_{0.02}\right.$

$\left.\mathrm{Al}_{0.20}\right)_{1.93}\left(\mathrm{Si}_{1.84} \mathrm{Al}_{0.16}\right)_{2.00} \mathrm{O}_{6}$ - pyroxene;

In the analysed field $1 a^{1}-3$ (Fig. $6 c$ ):

- Point 1: $\left(\mathrm{Fe}_{0.85} \mathrm{Ca}_{0.53} \mathrm{Mg}_{0.05} \mathrm{Mn}_{0.03} \mathrm{~K}_{0.05} \mathrm{Na}_{0.04}\right.$

$\left.\mathrm{Al}_{0.40}\right)_{1.95}\left(\mathrm{Si}_{1.92} \mathrm{Al}_{0.08}\right)_{2.00} \mathrm{O}_{6}$ - pyroxene;

In the analysed field $1 a^{1}-5$ (Fig. 6e):

- Point 1: $\left(\mathrm{Fe}_{1.10} \mathrm{Ca}_{0.18} \mathrm{~K}_{0.03} \mathrm{Al}_{0.14}\right)_{1.45}\left(\mathrm{Si}_{0.83} \mathrm{Al}_{0.14}\right.$

$\left.\mathrm{Ti}_{0.03}\right)_{1.00} \mathrm{O}_{4}$ - laihunite with impurities;

- Point 2: $\left(\mathrm{Fe}_{1.25} \mathrm{Ca}_{0.12} \mathrm{Mg}_{0.02} \mathrm{Mn}_{0.01} \mathrm{Na}_{0.03} \mathrm{~K}_{0.03}\right.$

$\left.\mathrm{Al}_{0.12}\right)_{1.58}\left(\mathrm{Si}_{0.83} \mathrm{Al}_{0.15} \mathrm{Ti}_{0.02}\right)_{1.00} \mathrm{O}_{4}$ - laihunite with impurities;

In the analysed field $1 a^{1}-6$ (Fig. 6f):

- Point 7: $\left(\mathrm{Fe}_{1.71} \mathrm{Mg}_{0.22} \mathrm{Ca}_{0.02} \mathrm{Mn}_{0.05}\right)_{2.00} \mathrm{Si}_{0.97} \mathrm{O}_{4}-$ fayalite;

- Point 8: slag glass with impurities of polishing material $-\mathrm{Cr}_{2} \mathrm{O}_{2}$ and $\mathrm{WO}_{3}$;

In the analysed field $1 a^{2}-1$ (Fig. $7 b$ ):

- Point 1: $\left(\mathrm{Fe}_{1.61} \mathrm{Mg}_{0.29} \mathrm{Mn}_{0.05} \mathrm{Ca}_{0.02}\right)_{1.97} \mathrm{Si}_{0.95} \mathrm{O}_{4}-$ fayalite;

- Point 2: $\left(\mathrm{Fe}_{1.60} \mathrm{Mg}_{0.31} \mathrm{Mn}_{0.05} \mathrm{Ca}_{0.02}\right)_{1.98} \mathrm{Si}_{0.96} \mathrm{O}_{4}-$ fayalite.

\section{Iron-oxide phases}

These phases are mainly isometric, incompletely formed magnetite crystals, which, during their rapid crystallization, absorbed part of the melt. For this reason, their composition does not correspond to exact stoichiometry and contains impurities from the silicate glass phase. Sulfide inclusions can perform the

Chemical composition of silicate phases in samples $1 a^{1}$ and $1 a^{2}$ according to data from elemental microanalyses (SEM CDD-EDS)

\begin{tabular}{|c|c|c|c|c|c|c|c|c|c|c|}
\hline \multirow{4}{*}{ Oxides } & \multicolumn{10}{|c|}{ Content, mass \% } \\
\hline & \multicolumn{8}{|c|}{ Sample $1 \mathrm{a}^{1}$} & \multirow{2}{*}{\multicolumn{2}{|c|}{$\begin{array}{c}\text { Sample } 1 \mathrm{a}^{2} \\
\text { An. field } \\
1 \mathrm{a}^{2}-1 \\
\text { (Fig. } 7 b \text { ) }\end{array}$}} \\
\hline & \multicolumn{2}{|c|}{$\begin{array}{l}\text { An. field } \\
1 a^{1}-1 \\
\text { (Fig. 6a) }\end{array}$} & \multirow{2}{*}{$\begin{array}{c}\text { An. field } \\
1 a^{1}-2 \\
(\text { Fig. 6b) } \\
\begin{array}{c}\text { Point } 8 \\
\text { (Py) }\end{array}\end{array}$} & \multirow{2}{*}{$\begin{array}{l}\text { An. field } \\
1 \mathrm{a}^{1}-3 \\
\text { (Fig. 6c) } \\
\text { Point } 1 \\
\text { (Py) }\end{array}$} & \multicolumn{2}{|c|}{$\begin{array}{l}\text { An. field } \\
1 \mathrm{a}^{1}-5 \\
\text { (Fig. 6e) }\end{array}$} & \multicolumn{2}{|c|}{$\begin{array}{l}\text { An. field } \\
1 \mathrm{a}^{1}-6 \\
\text { (Fig. } 6 f)\end{array}$} & & \\
\hline & $\begin{array}{l}\text { Point } 1 \\
(\mathrm{Fa})\end{array}$ & $\begin{array}{c}\text { Point } 2 \\
(\mathrm{Fa})\end{array}$ & & & $\begin{array}{c}\text { Point } 1 \\
\text { (La) }\end{array}$ & $\begin{array}{c}\text { Point } 2 \\
\text { (La) }\end{array}$ & $\begin{array}{c}\text { Point } 7 \\
\text { (Fa) }\end{array}$ & $\begin{array}{l}\text { Point } 8 \\
\text { (Glass) }\end{array}$ & $\begin{array}{c}\text { Point } 1 \\
(\mathrm{Fa})\end{array}$ & $\begin{array}{c}\text { Point } 2 \\
\text { (Fa) }\end{array}$ \\
\hline $\mathrm{SiO}_{2}$ & 30.05 & 30.02 & 45.43 & 48.26 & 31.82 & 30.10 & 29.98 & 39.52 & 30.30 & 30.40 \\
\hline $\mathrm{FeO}$ & 62.47 & 62.70 & 31.32 & 25.60 & 50.20 & 53.88 & 62.77 & 25.82 & 60.94 & 60.49 \\
\hline $\mathrm{MgO}$ & 4.74 & 4.38 & 1.58 & 0.83 & - & 0.39 & 4.54 & 2.83 & 6.10 & 6.53 \\
\hline $\mathrm{MnO}$ & 2.07 & 2.14 & 1.33 & 0.99 & 0.59 & 1.96 & 1.96 & - & 2.02 & 1.91 \\
\hline $\mathrm{CaO}$ & 0.66 & 0.77 & 11.97 & 12.33 & 6.39 & 4.18 & 0.76 & 12.72 & 0.64 & 0.67 \\
\hline $\mathrm{Al}_{2} \mathrm{O}_{3}$ & - & - & 7.64 & 10.28 & 9.42 & 8.38 & - & 8.45 & - & - \\
\hline $\mathrm{TiO}_{2}$ & - & - & - & - & 1.33 & 1.16 & - & - & - & - \\
\hline $\mathrm{Na}_{2} \mathrm{O}$ & - & - & 0.30 & - & - & 0.49 & - & - & - & - \\
\hline $\mathrm{K}_{2} \mathrm{O}$ & - & - & 0.44 & 1.14 & 0.84 & 0.83 & - & - & - & - \\
\hline $\mathrm{Cr}_{2} \mathrm{O}_{3}$ & - & - & - & - & - & - & - & 1.62 & - & - \\
\hline $\mathrm{WO}_{3}$ & - & - & - & - & - & - & - & 9.04 & - & - \\
\hline
\end{tabular}

Abbreviations: fayalite (Fa), laihunite (La), pyroxene (Py), slag glass (Glass). 
role of crystallization centres, around which magnetite grows (Mihailova, 2009). This is a possible explanation for the presence of copper content in these phases.

\section{Copper and residual sulfide phases in copper- containing aggregates}

Copper-containing phases in samples $1 a^{1}$ and $1 a^{2}$ are chalcocite, pure copper droplets and aggre- gates with copper-iron-sulfide composition. Microscopically, in reflected light, the aggregates were observed with a close to spherical shape. The chemical composition of the studied coppercontaining phases is presented in Table 4. Studies on the copper $(\mathrm{Cu})$ and sulfur $(\mathrm{S})$ distribution in the copper-sulfide aggregates show that sulfur is fully concentrated in their periphery (Fig. $7 g, h$; Table 4).
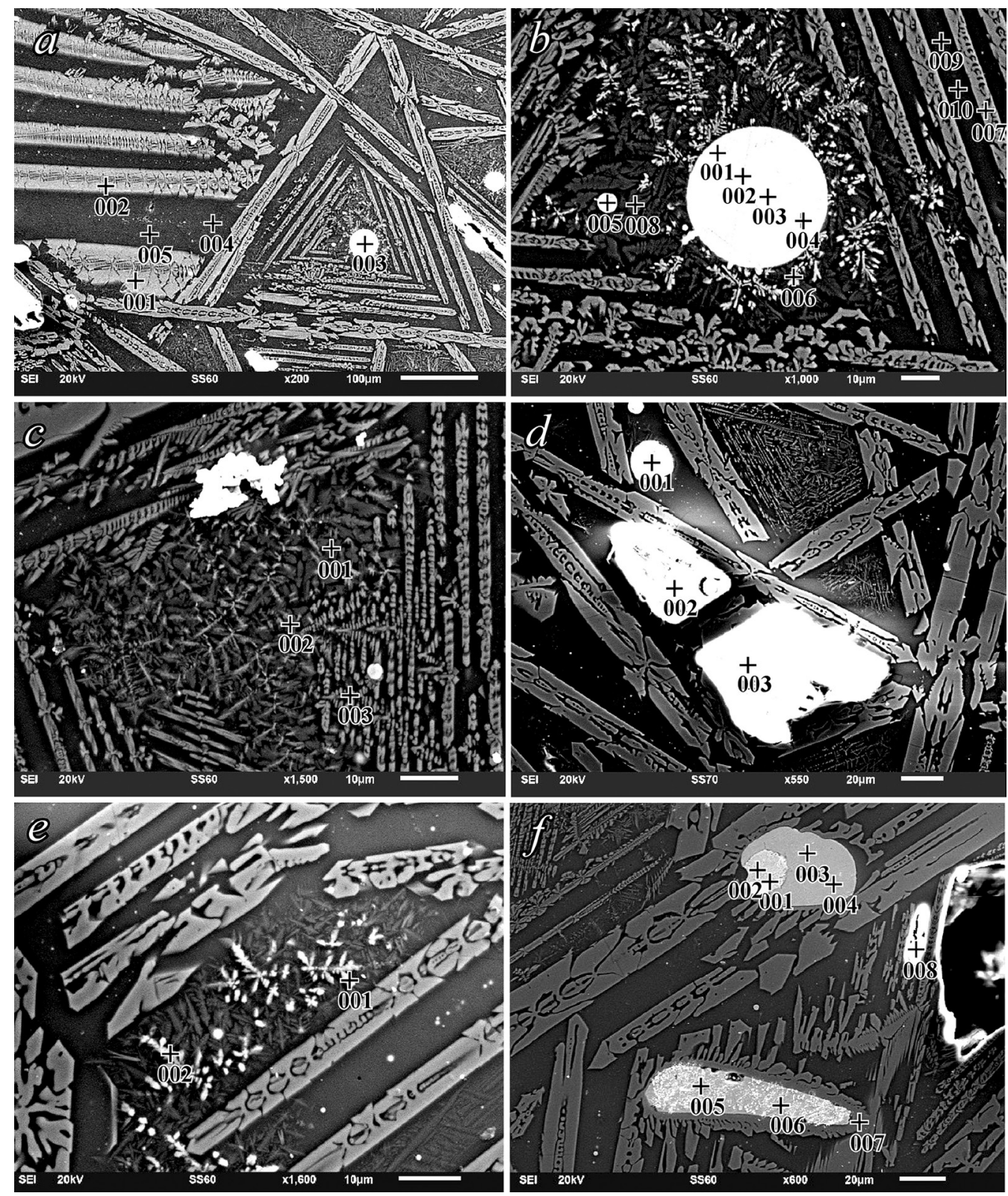

Fig. 6. Scanning electron microscope images of the phases identified in sample $1 a^{1}$ and CDD-EDS mapping of analysed points: a) analysed field $1 \mathrm{a}^{1}-1$ with points: 1 (fayalite), 2 (fayalite), 3 (aggregate - chalcocite), 4 (slag glass) and 5 (slag glass); $b$ ) analysed field $1 \mathrm{a}^{1}-2$ with points: 1 (digenite), 2 (chalcocite), 3 (chalcocite), 4 (chalcocite), 5 (copper-iron-sulfide aggregate), 6 (magnetite), 7 (fayalite), 8 (pyroxene), 9 (slag glass) and 10 (slag glass); c) analysed field $1 \mathrm{a}^{1}-3$ with points: 1 (pyroxene), 2 (pyroxene) and 3 (solid solution between fayalite and laihunite); $d$ ) analysed field $1 a^{1}-4$ with points: 1, 2, 3 (copper-containing aggregates); $e$ ) analysed field $1 a^{1}-5$ with points: 1 (laihunite) and 2 (laihunite); f) analysed field 1a $1 a^{1} 6$ with points: 1, 2, 3, 4, 5, 6 (copper-containing aggregates), 7 (fayalite) and 8 (slag glass). 

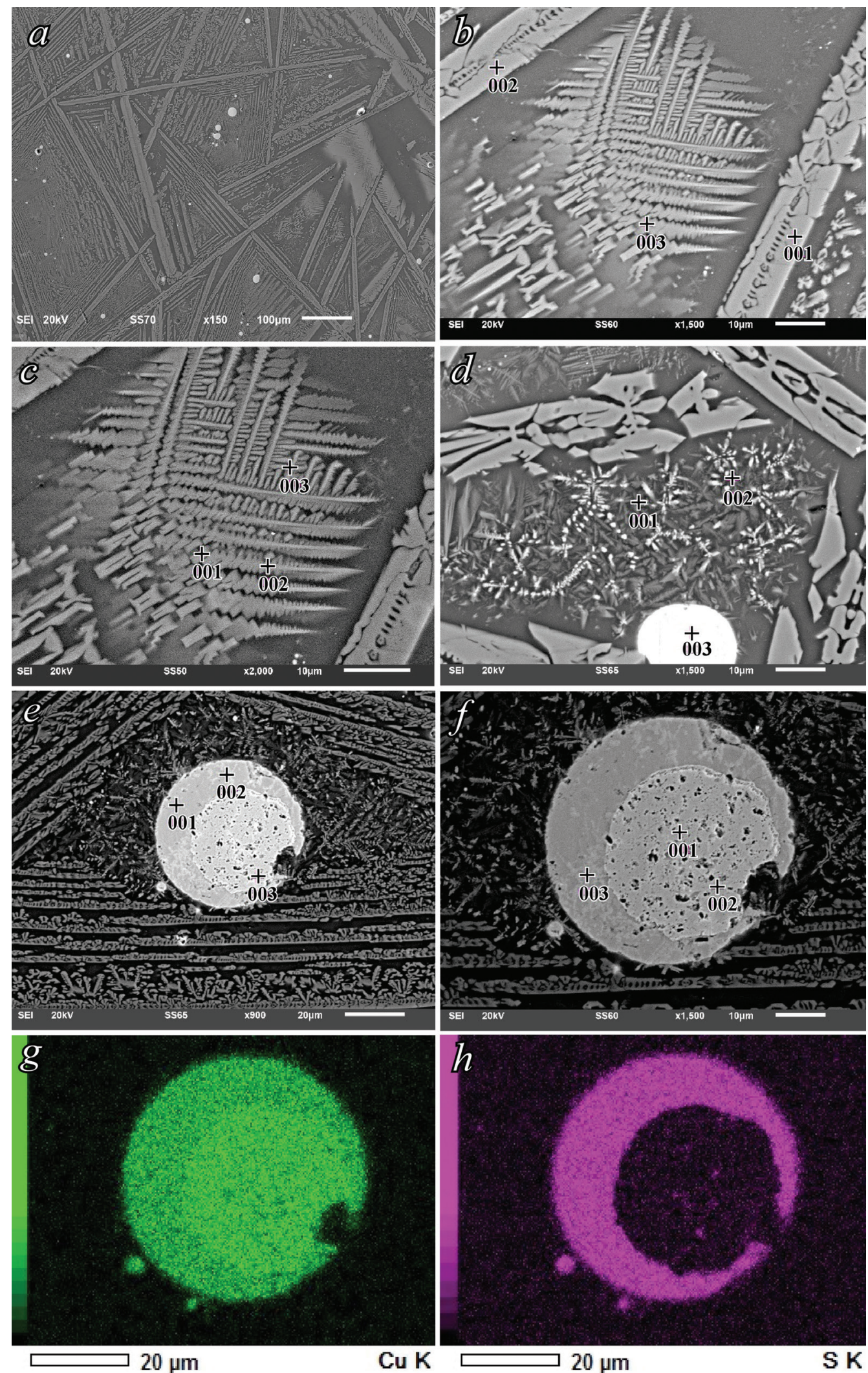

Fig. 7. Scanning electron microscope images of the phases identified in sample $1 \mathrm{a}^{2}$ and CDD-EDS mapping of analysed points: $a$ ) overview with huge fayalite crystals; $b$ ) analysed field $1 a^{2}-1$ with points: 1 (fayalite), 2 (fayalite) and 3 (fayalite); $c$ ) analysed field $1 \mathrm{a}^{2}-2$ with points $1,2,3 ; d$ ) analysed field $1 \mathrm{a}^{2}-4$ with points: 1,2 and 3 (copper-sulfide aggregate); $e$ ) analysed field $1 \mathrm{a}^{2}-5$ with points: 1 (chalcocite), 2 (chalcocite) and 3 (aggregate - copper with iron); $f$ ) analysed field $1 \mathrm{a}^{2}-6$ with points: 1 (copper), 2 (aggregate - copper with iron) and 3 (aggregate - copper with sulfur); $g$ ) distribution of copper (Cu) in a copper-sulfide aggregate - the concentration is higher in its central part; $h$ ) distribution of sulfur (S) in a copper-sulfide aggregate - it is concentrated in the periphery of the aggregate. 
Table 4

Chemical composition of copper-containing phases and aggregates in samples $1 a^{1}$ and $1 a^{2}$ according to data from elemental microanalyses (SEM CDD-EDS)

\begin{tabular}{|c|c|c|c|c|c|c|c|c|c|c|c|}
\hline \multirow{4}{*}{$\begin{array}{l}\text { Chemical } \\
\text { element }\end{array}$} & \multicolumn{11}{|c|}{ Content, mass \% } \\
\hline & \multicolumn{4}{|c|}{ Sample $1 \mathrm{a}^{1}$} & \multicolumn{7}{|c|}{ Sample $1 \mathrm{a}^{2}$} \\
\hline & \multicolumn{4}{|c|}{$\begin{array}{c}\text { Analysed field } \\
1 a^{1}-2 \\
\text { (Fig. 6b) }\end{array}$} & \multirow{2}{*}{$\begin{array}{c}\text { Analysed field } \\
\begin{array}{c}1 \mathrm{a}^{2}-4 \\
(\text { Fig. } 7 d)\end{array} \\
\text { Point } 3\end{array}$} & \multicolumn{3}{|c|}{$\begin{array}{c}\text { Analysed field } \\
1 \mathrm{a}^{2}-5 \\
\text { (Fig. 7e) }\end{array}$} & \multicolumn{3}{|c|}{$\begin{array}{c}\text { Analysed field } \\
1 \mathrm{a}^{2}-6 \\
\text { (Fig. 7f) }\end{array}$} \\
\hline & Point 2 & Point 3 & Point 4 & Point 5 & & Point 1 & Point 2 & Point 3 & Point 1 & Point 2 & Point 3 \\
\hline $\mathrm{Cu}$ & 78.43 & 78.81 & 78.30 & 65.86 & 77.52 & 80.32 & 80.51 & 98.68 & 99.15 & 98.94 & 80.46 \\
\hline $\mathrm{Fe}$ & 1.44 & 1.29 & 1.67 & 8.82 & 2.47 & - & - & 1.32 & 0.85 & 1.06 & - \\
\hline $\mathrm{S}$ & 20.14 & 19.89 & 20.03 & 25.32 & 20.01 & 19.68 & 19.49 & - & - & - & 19.54 \\
\hline
\end{tabular}

In the analysed field $1 a^{1}-2$ (Fig. $6 b$ ) the following phases were calculated:

- Point 2: $\mathrm{Cu}_{1.96} \mathrm{Fe}_{0.04} \mathrm{~S}$ - chalcocite;

- Point 3: $\mathrm{Cu}_{2.00} \mathrm{Fe}_{0.03} \mathrm{~S}$ - chalcocite;

- Point 4: $\mathrm{Cu}_{1.97} \mathrm{Fe}_{0.04} \mathrm{~S}$ - chalcocite;

- Point 5: $\mathrm{Cu}_{1.31} \mathrm{Fe}_{0.20} \mathrm{~S}$ - copper-iron-sulfide aggregate;

In the analysed field $1 a^{2}-4$ (Fig. $7 d$ ):

- Point 3: copper-iron-sulfide aggregate;

In the analysed field $1 a^{2}-5$ (Fig. 7e):

- Point 1: chalcocite;

- Point 2: chalcocite;

- Point 3: copper-iron aggregate;
In the analysed field $1 a^{2}-6$ (Fig. 7f):

- Point 1: copper;

- Point 2: copper-iron aggregate;

- Point 3: copper-sulfide aggregate.

\section{Mineralogy and phase composition of slag sample 2}

\section{Powder XRD analysis}

The XRD study of sample 2 (Fig. 8) shows the following phases in the slag composition: fayalite $\mathrm{Fe}_{2} \mathrm{SiO}_{4}$, augite $\mathrm{Ca}\left(\mathrm{Mg}, \mathrm{Fe}^{3+}, \mathrm{Al}\right)(\mathrm{Si}, \mathrm{Al})_{2} \mathrm{O}_{6}$ (Aug) and laihunite- $1 \mathrm{M} \mathrm{Fe}_{1,6} \mathrm{SiO}_{4}(\mathrm{La})$.

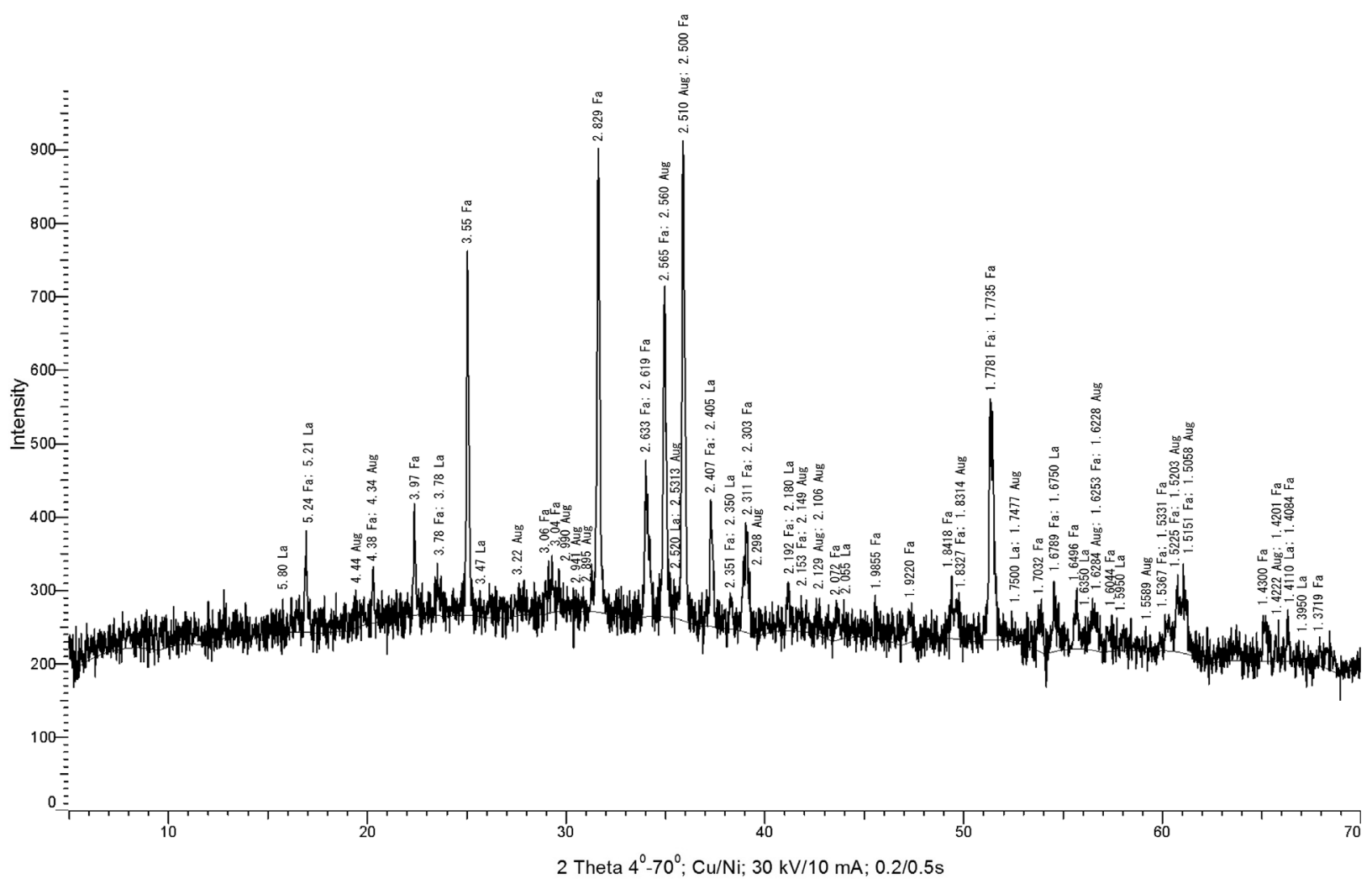

Fig. 8. XRD graph of sample 2: fayalite (Fa), augite (Aug) and laihunite-1M (La). 


\section{Light optical microscopy}

This slag sample differs significantly from samples $1 \mathrm{a}^{1}$ and $1 \mathrm{a}^{2}$ in having more parallel skeletal forms of defective crystals and copper-sulfide aggregates (Fig. 9a). The predominant crystal phase is fayalite with prismatic skeletal crystals and subradial aggregates (Fig. $9 b-d$ ). Some of the prismatic crystals are pyroxene-type, which matches the results from the XRD study of the sample (Fig. 8). This slag contains more ore relics, such as bornite, chalcopyrite and copper-containing aggregates, in comparison with other studied samples. The copper metal droplets and copper-sulfide spherical aggregates with high reflectivity were observed as included in the slag glass matrix, as well as between the prismatic crystalline phases (Fig. 9a). Some of them contain numerous small yellow-pink microspheres of copper sulfides (chalcopyrite?).

\section{Silicate phases}

The crystal silicate phases in this sample (mainly fayalite and pyroxene) are parallel skeletal forms
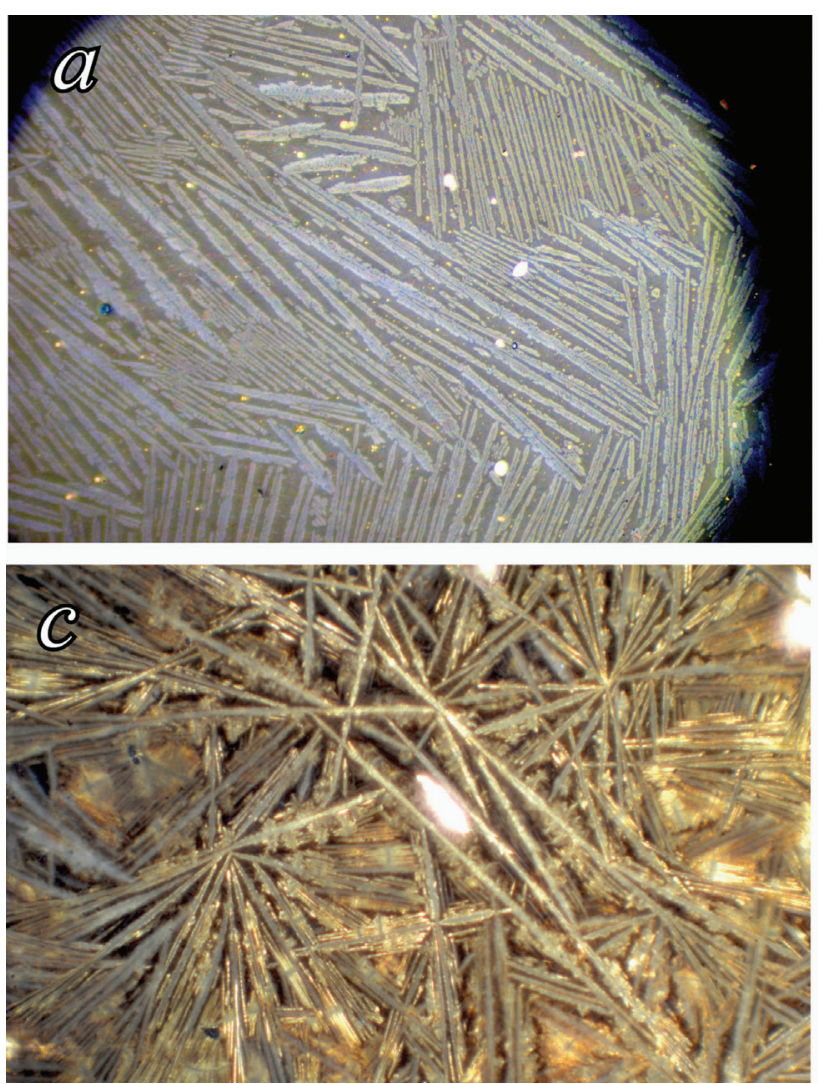

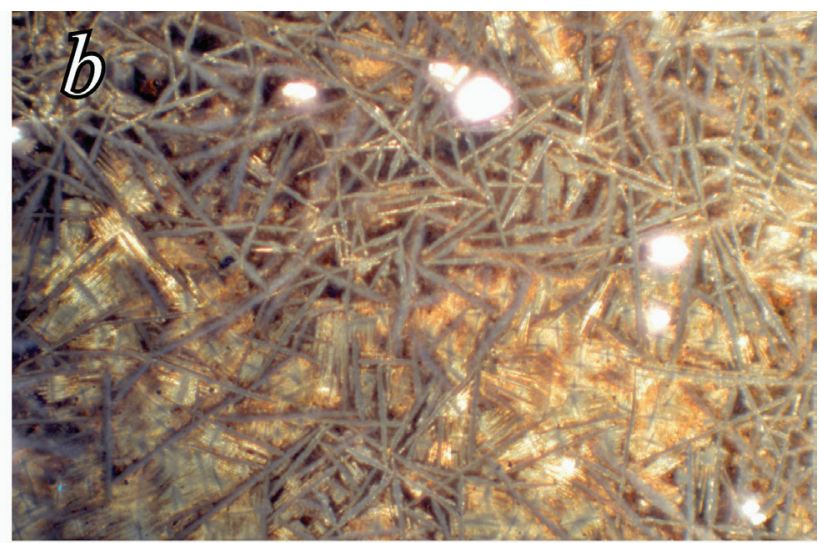

of defective crystals. Their composition differs from the exact stoichiometry because of the included impurities from the slag melt. The variations in chemical compositions of these phases are given in Table 5.

The chemical composition of a fayalite crystal from analysed field 2-5, point 2 (Fig. 10f) is the following: $\mathrm{SiO}_{2}$ (31.82\%), $\mathrm{FeO}$ (61.39\%), $\mathrm{CaO}$ (1.68\%), $\mathrm{MgO}$ (4.02\%), $\mathrm{Al}_{2} \mathrm{O}_{3}(0.62 \%)$ and $\mathrm{K}_{2} \mathrm{O}$

Table 5

Variations in the chemical composition of the crystal silicate phases in sample 2 (from 6 analysed points) according to data from elemental microanalyses (SEM CDD-EDS)

\begin{tabular}{cc}
\hline Oxides & Mass \% \\
\hline $\mathrm{SiO}_{2}$ & $31.62-34.97$ \\
$\mathrm{FeO}$ & $56.39-61.39$ \\
$\mathrm{MgO}$ & $1.95-4.02$ \\
$\mathrm{CaO}$ & $1.68-2.63$ \\
$\mathrm{Al}_{2} \mathrm{O}_{3}$ & $0.62-2.49$ \\
$\mathrm{~K}_{2} \mathrm{O}$ & $0-0.47$ \\
\hline
\end{tabular}

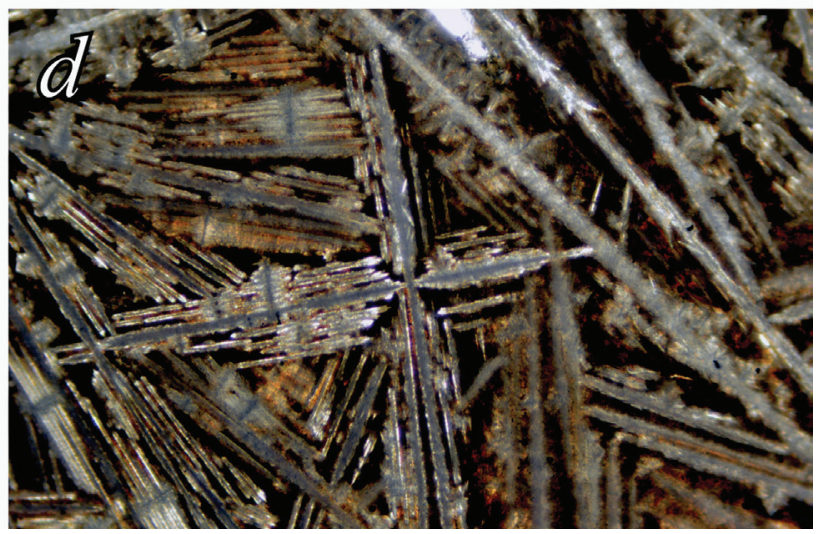

Fig. 9. Microstructure of slag sample 2, light microscopy: $a$ ) overview of slag sample 2 and copper-sulfide spherical aggregates, $\times 20$, plane-polarized reflected light; $b$ ) prismatic fayalite crystals, $\times 4$, plane-polarized transmitted light; $c$ ) radiating and subradiating aggregates of fayalite crystals, $\times 4$, plane-polarized transmitted light; $d$ ) radiating and sub-radiating aggregates of fayalite crystals, $\times 10$, plane-polarized transmitted light. 
(0.47\%), with calculated formula $\left(\mathrm{Fe}_{1.65} \mathrm{Mg}_{0.19}\right.$. $\left.\mathrm{Ca}_{0.06} \mathrm{Al}_{0.02} \mathrm{~K}_{0.02}\right)_{1.94} \mathrm{Si}_{1.02} \mathrm{O}_{4}$.

\section{Copper and residual sulfide phases in copper- containing aggregates}

In this sample, in reflected light, we observed copper-containing inhomogeneous inclusions (Fig. 9a) and many very small microspheres with a yellow- pink colour. The latter are copper-iron sulfides with composition close to chalcopyrite. All six elemental microanalyses (SEM CDD-EDS) in studied fields 2-1 and 2-2 showed the presence of copper-iron sulfide inclusions in the sample. The results are listed below.

Table 6 presents the phase compositions of five elemental microanalyses in copper-containing aggregates from analysed field 2-2 (Fig. 10c). Ana-
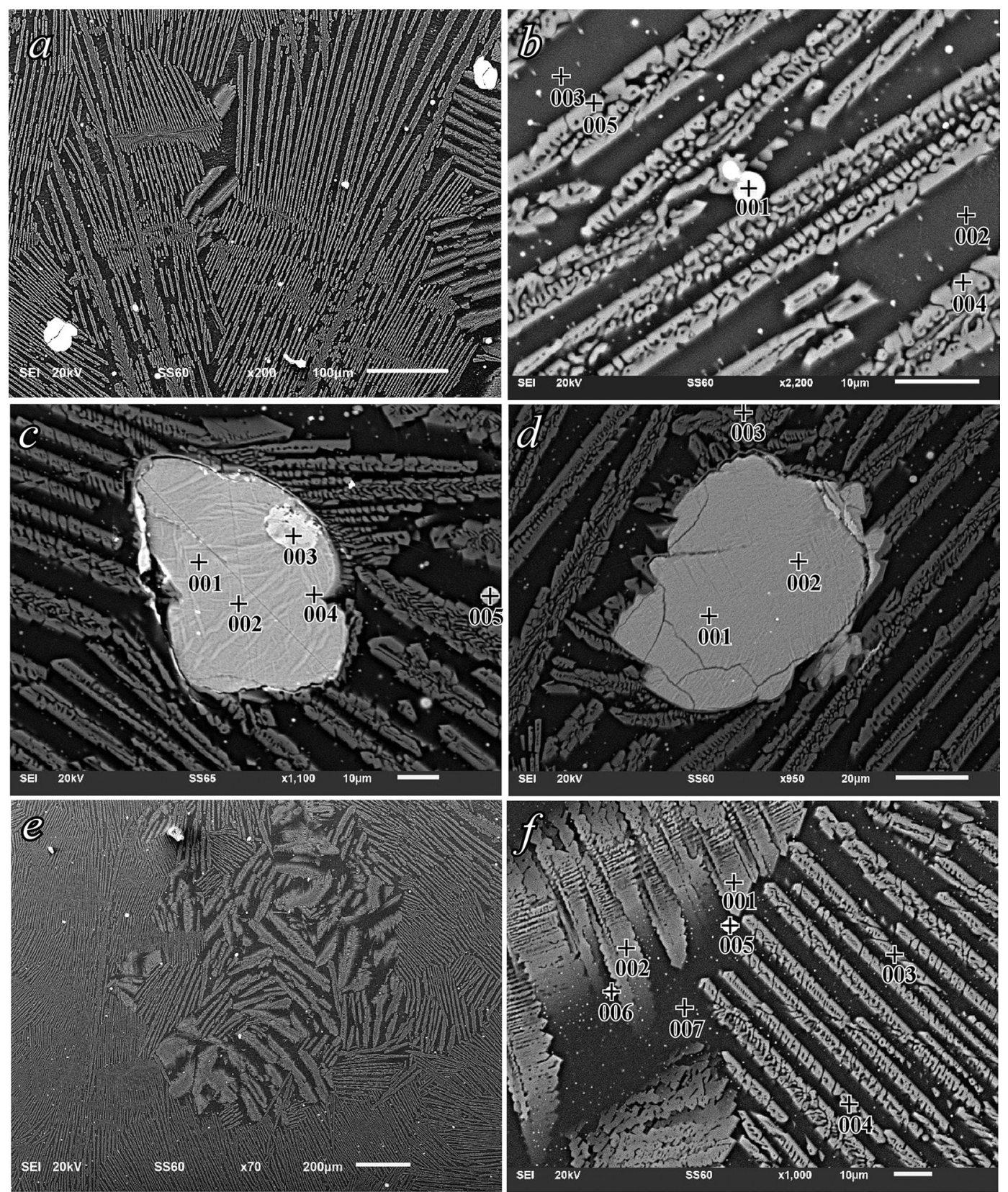

Fig. 10. Scanning electron microscope images of the phases identified in sample 2 and CDD-EDS mapping of analysed points: a) overview; $b$ ) analysed field 2-1 with points: 1 (copper-containing aggregate), 2, 3 (slag glass), 4, 5 (fayalite crystals); $c$ ) analysed field 2-2 - copper-containing aggregates with points 1, 2, 3, 4 and 5; d) analysed field 2-3 with points 1, 2 (copper-containing aggregates), 3 (fayalite); e) microfield with a coarser-grained structure; $f$ ) analysed field 2-5 with point 2 being a fayalite crystal, points 5 and 6 - copper-containing aggregates, point 7 - slag glass. 
Table 6

Chemical composition of copper-containing aggregates in sample 2, analysed field 2-2

(Fig. 10c) according to data from elemental microanalyses (SEM CDD-EDS)

\begin{tabular}{ccccccc}
\hline \multirow{2}{*}{$\begin{array}{c}\text { Chemical } \\
\text { elements }\end{array}$} & $\mathrm{Cu}$ & $\mathrm{Fe}$ & $\mathrm{S}$ & $\mathrm{Si}$ & $\mathrm{O}$ & $\mathrm{Cd}$ \\
\cline { 2 - 7 } & 65.30 & 10.26 & 24.44 & - & - & - \\
\hline Point 1 & 65.22 & 10.32 & 24.46 & - & - & - \\
Point 2 & 96.11 & 2.41 & - & - & 1.48 & - \\
Point 3 & 57.66 & 14.60 & - & - & 4.46 & - \\
Point 4 & 22.97 & 32.17 & 22.90 & 7.76 & 11.93 & 2.26 \\
Point 5 & & & & & & \\
\hline
\end{tabular}

lysed point 3 is a drop rich in copper. Points 1 and 2 are from an inhomogeneous inclusion with a composition of iron-copper sulfide close to bornite.

The chemical composition in points 1 and 2 in the analysed field 2-2 (Fig. 10c, Table 6) is very close to bornite $\left(\mathrm{Cu}_{5} \mathrm{FeS}_{4}\right)$. For point 1 , it is $\mathrm{Cu}_{5.39} \mathrm{Fe}_{0.096} \mathrm{~S}_{4}$. Results from the chemical study of point 3 show that it is almost pure copper with very low iron content and slightly oxidized. The melting process for sample 2 took place at lower temperatures and, therefore, some free copper and residual sulfide phases were registered.

\section{Mineralogy and phase composition of slag sample 3a}

\section{Powder XRD analysis}

The slags of samples $3 a^{1}$ and $3 a^{2}$ are mainly composed of silicate and iron oxide phases. For slag group $3 \mathrm{a}^{1}$, XRD study registers fayalite $\mathrm{Fe}_{2} \mathrm{SiO}_{4}$ (Fa), magnesium fayalite (olivine, $\mathrm{Ol})(\mathrm{Fe}, \mathrm{Mg})_{2} \mathrm{SiO}_{4}$, kirschsteinite $\mathrm{CaFe}^{2+} \mathrm{SiO}_{4}$ (Kir) and laihunite- $1 \mathrm{M} \mathrm{Fe}_{1.6} \mathrm{SiO}_{4}(\mathrm{La})$ (Fig. 11). X-ray study of sample $3 \mathrm{a}^{2}$ indicates the presence of fayalite $\mathrm{Fe}_{2} \mathrm{SiO}_{4}(\mathrm{Fa})$, kirschsteinite

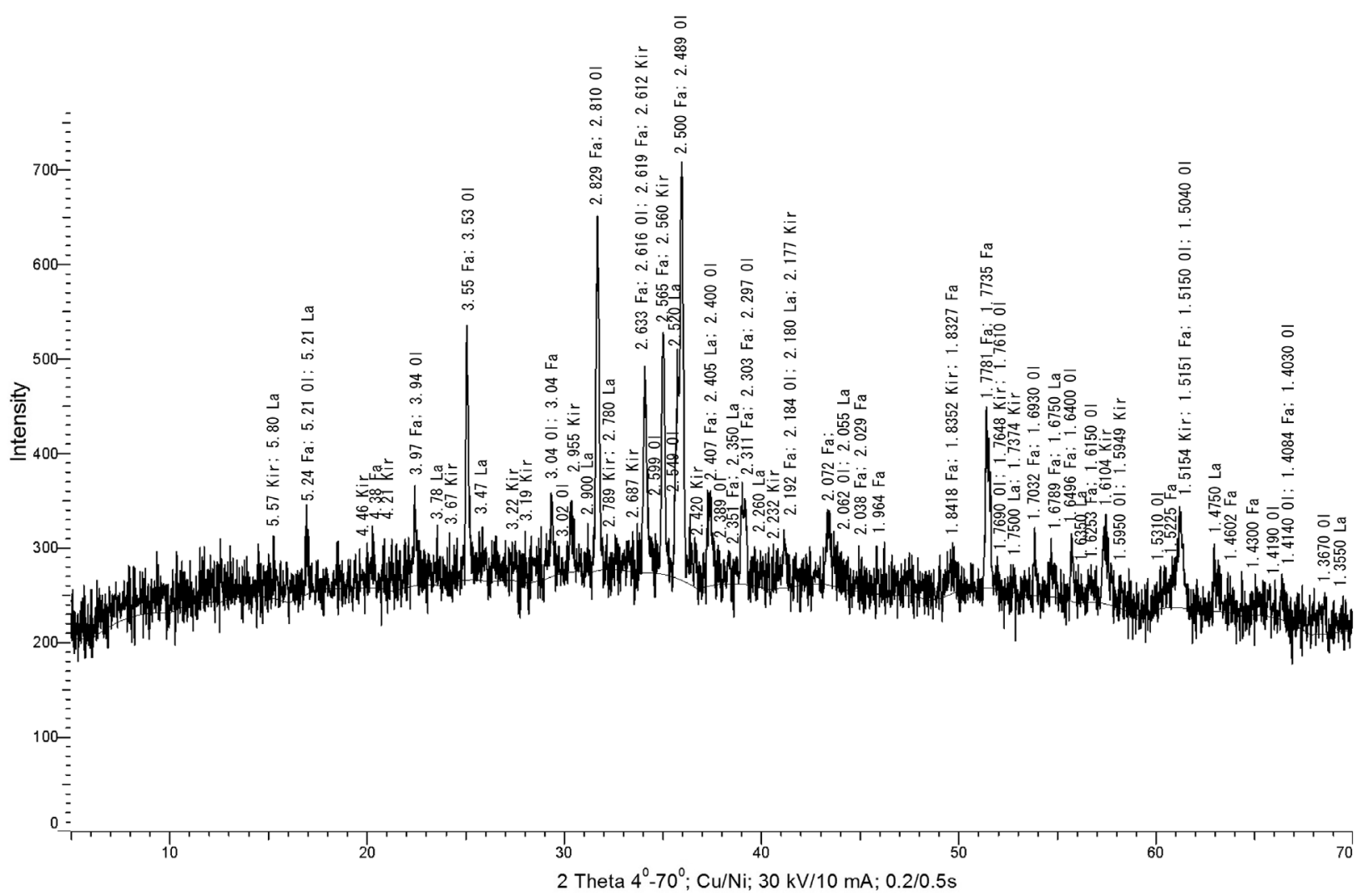

Fig. 11. XRD graph of sample $3 \mathrm{a}^{1}$ : fayalite (Fa), magnesium fayalite (olivine, Ol), kirschsteinite (Kir) and laihunite-1M (La). 
$\mathrm{CaFe}^{2+} \mathrm{SiO}_{4}$ (Kir), augite $\mathrm{Ca}\left(\mathrm{Mg}, \mathrm{Fe}^{3+}, \mathrm{Al}\right)(\mathrm{Si}, \mathrm{Al})_{2} \mathrm{O}_{6}$ (Aug) and magnetite $\mathrm{Fe}^{2+} \mathrm{Fe}^{3+}{ }_{2} \mathrm{O}_{4}$ (Mag) (Fig. 12).

\section{Light optical microscopy}

Sample $3 a^{1}$. This sample is coarse-grained and contains fewer pores than sample $3 \mathrm{a}^{2}$. Fayalite is the dominant crystalline phase, followed by magnetite/ maghemite and copper-sulfide aggregates included in the slag glass matrix. Fayalite occurs as huge prismatic skeletal crystals (Fig. 13a, b) or shows textures with dendritic or irregular skeletal crystals indicating rapid crystallization (Fig. 13c). The $\mathrm{X}$-ray diffraction pattern of sample $3 \mathrm{a}^{1}$ revealed the presence of the fayalite, magnesium fayalite (olivine), kirschsteinite and laihunite phases (Fig. 11). This slag is rich in magnetite, observed as pale-grey crystals with brownish tinges in reflected light. Magnetite occurs either in skeletons or as dendritic aggregates (Fig. 13d). Grains of metallic copper and copper-sulfide aggregates show bright orangy red colour and higher reflectivity than the surrounding magnetite grains. The aggregates contain relics from bornite and covellite with yellow-pink and indigo blue colour in reflected light, respectively (Fig. 13d).

Sample $3 a^{2}$. The material is highly porous, with huge prismatic skeletal fayalite crystals (Fig. 13e).
This sample is probably from the more rapid cooling section of the molten material. Some fayalites have included in themselves ore mineral grains. The slag is full of isometric skeletal magnetite crystals and dendritic aggregates (Fig. 13e-g). Coppersulfide aggregates are inhomogeneous, with an irregular shape. They also contain in their rims relics from ore minerals (Fig. 13h). The X-ray diffraction pattern of sample $3 \mathrm{a}^{2}$ confirms the presence in the slag of fayalite, magnetite, kirschsteinite and augite (Fig. 12).

\section{Silicate phases}

Well-defined lamellar forms of fayalite were studied in points 1 and 2 of the analyszed field $3 a^{1}-1$ (Fig. 14a) and in field $3 a^{2}-1$ (Fig. 15a). The results of these analyses are presented in Table 7.

The analysed fayalite individuals have the following crystal-chemical formulas:

In the analysed field $3 a^{1}-1$ (Fig. 14a):

- Point 1: $\mathrm{Fe}_{1.76} \mathrm{Mg}_{0.20} \mathrm{Ca}_{0.04} \mathrm{Si}_{1.00} \mathrm{O}_{4}$;

- Point 2: $\mathrm{Fe}_{1,72} \mathrm{Mg}_{0,22} \mathrm{Ca}_{0,01} \mathrm{Si}_{1,00} \mathrm{O}_{4}$;

In the analysed field $3 a^{2}-1$ (Fig. 15a):

- Point 3: $\mathrm{Fe}_{1.71} \mathrm{Mg}_{0.29} \mathrm{Ca}_{0.01} \mathrm{Mn}_{0.03} \mathrm{Al}_{0.01} \mathrm{Si}_{0.97} \mathrm{O}_{4}$;

- Point 4: $\mathrm{Fe}_{1.81} \mathrm{Mg}_{0.22} \mathrm{Ca}_{0.01} \mathrm{Mn}_{0.03} \mathrm{Si}_{0.97} \mathrm{O}_{4}$.

All compositions of the iron-silicate phases in samples $3 a^{1}$ and $3 a^{2}$ are very close to the stoichiom-

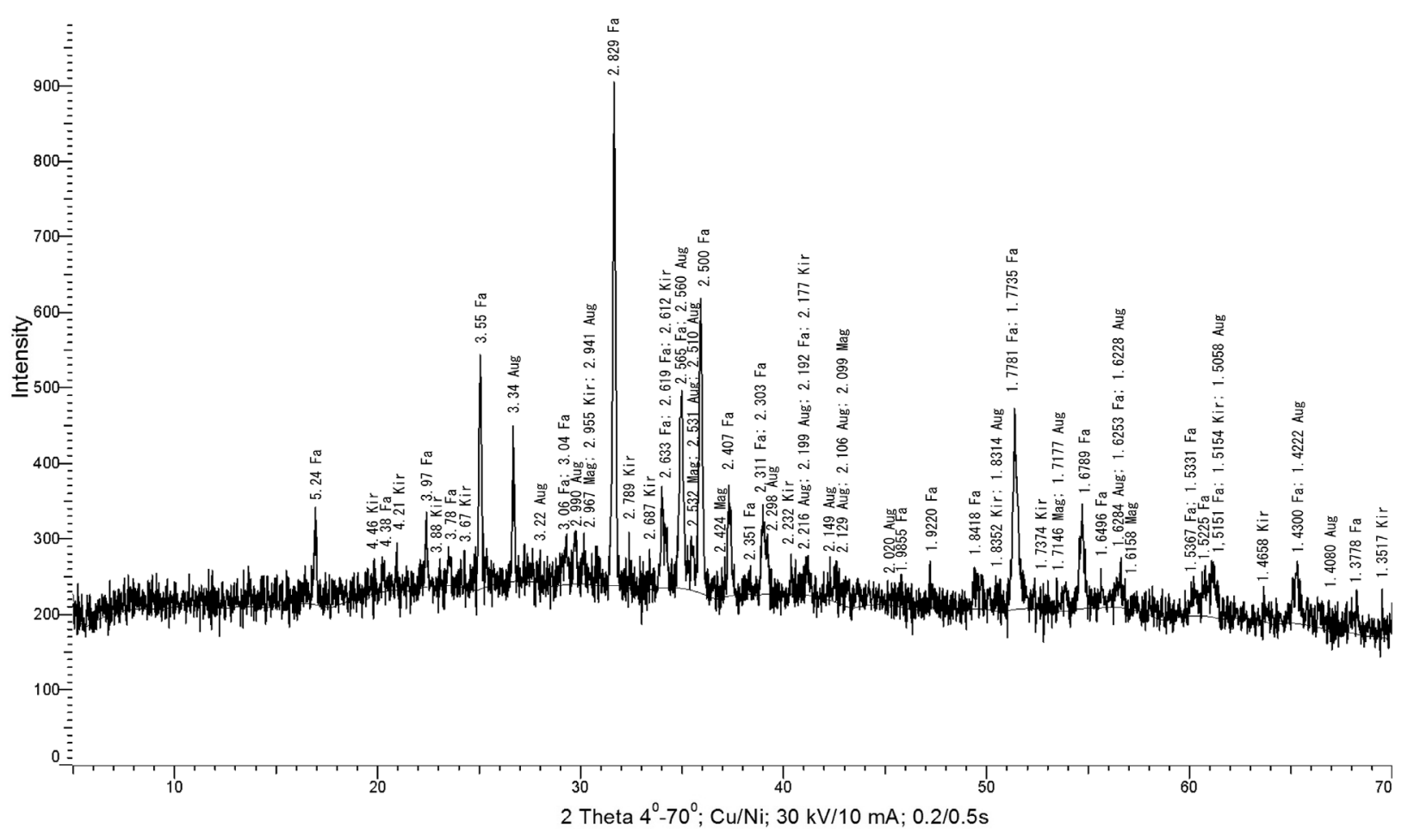

Fig. 12. XRD graph of sample $3 a^{2}$ : fayalite (Fa), kirschsteinite (Kir), augite (Aug) and magnetite (Mag). 

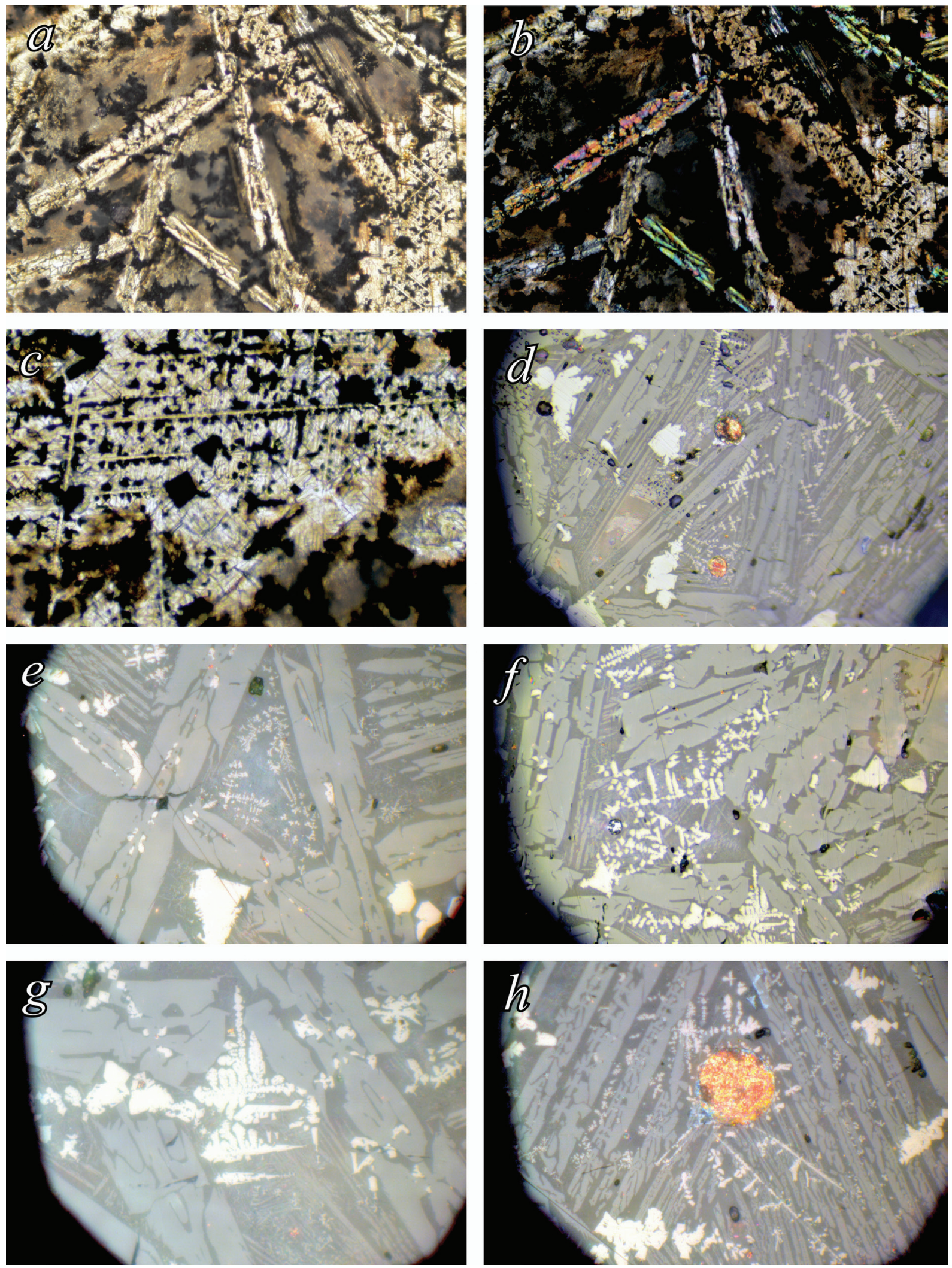

Fig. 13. Microstructure of sample 3a, light microscopy: a) prismatic skeletal fayalite crystals, $\times 10$, plane-polarized transmitted light; $b$ ) prismatic skeletal fayalite crystals, $\times 10$, cross-polarized transmitted light; $c$ ) dendritic and irregular skeletal fayalite crystals, $\times 20$, plane-polarized transmitted light; $d$ ) magnetite and copper-sulfide aggregates, $\times 20$, plane-polarized reflected light; e) prismatic skeletal fayalite crystals, $\times 40$, plane-polarized reflected light; $f$ ) fayalite, magnetite and sulfide inclusions, $\times 20$, planepolarized reflected light; $g$ ) dendritic magnetite aggregates, $\times 40$, plane-polarized reflected light; $h$ ) inhomogeneous copper-sulfide aggregate, $\times 40$, plane-polarized reflected light. 

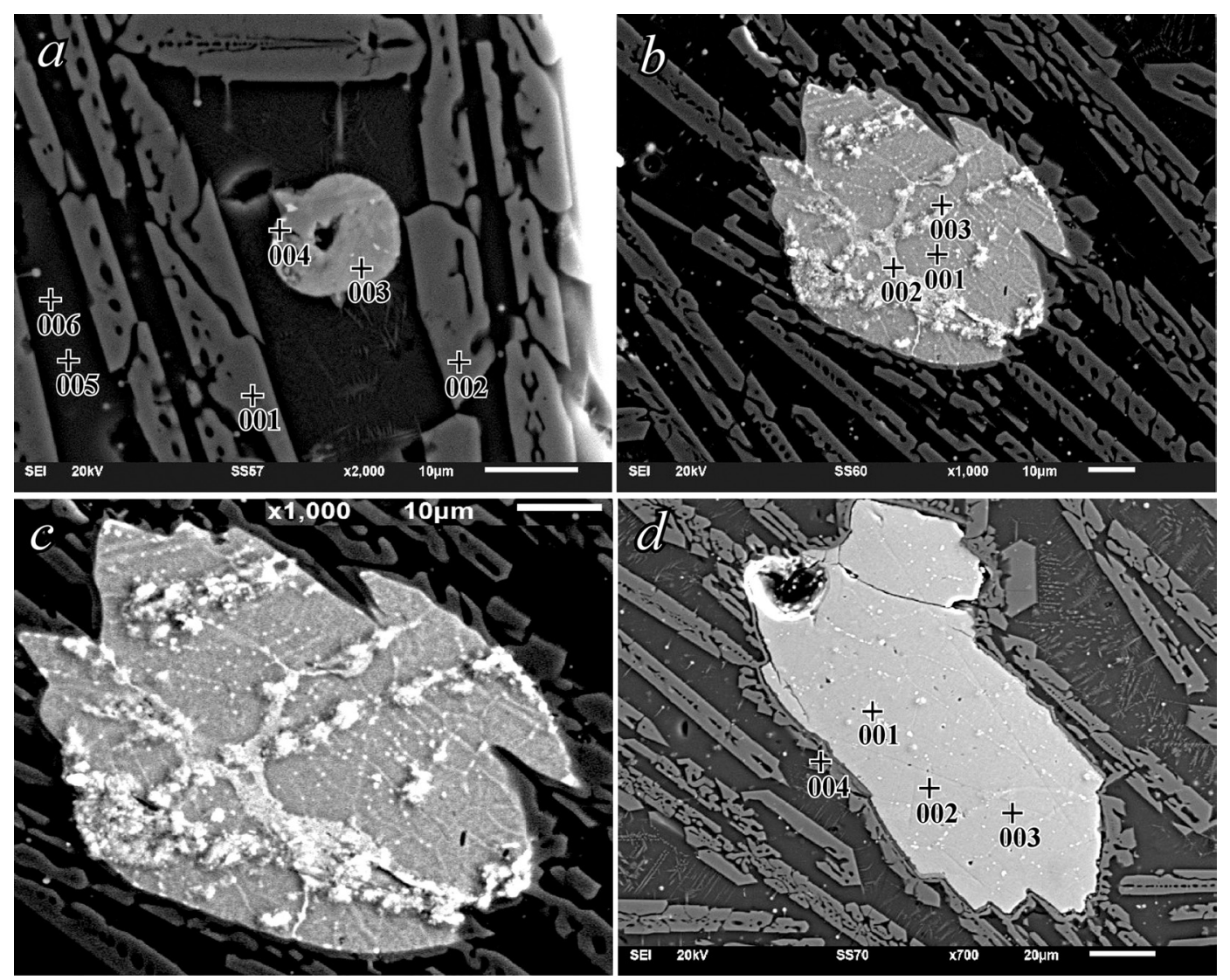

Fig. 14. Scanning electron microscope images of the phases identified in sample $3 a^{1}$ and CDD-EDS mapping of analysed points: a) analysed field $3 a^{1}-1$ with points: 1 , 2 (fayalite), 3, 4 (copper-containing aggregates), 5, 6 (slag glass); $b$ ) analysed field 3a ${ }^{1}-2$ with points 1, 2, 3 (iron-copper sulfide phases); $c$ ) relic of the raw material in the close-up; $d$ ) analysed field $3 a^{1}-3$ with points $1,2,3$ (iron-copper sulfide phases) and 4 (magnetite/maghemite).

Table 7

Chemical composition of fayalite crystals in samples $3 a^{1}$ and $3 a^{2}$ according to data from elemental microanalyses (SEM CDD-EDS)

\begin{tabular}{lcccc}
\hline \multirow{2}{*}{ Oxides } & \multicolumn{4}{c}{ Content, mass \% } \\
\cline { 2 - 5 } & \multicolumn{2}{c}{ Sample 3a $^{1}$} & \multicolumn{2}{c}{ Sample 3a $^{2}$} \\
\cline { 2 - 5 } & \multicolumn{2}{c}{ Analysed field 3a ${ }^{1}$-1 (Fig. 14a) } & Analysed field 3a ${ }^{2}$-1 (Fig. 15a) \\
\cline { 2 - 5 } & Point 1 (Fa) & Point 2 (Fa) & Point 3 (Fa) & Point 4 (Fa) \\
\hline $\mathrm{SiO}_{2}$ & 30.34 & 30.38 & 29.65 & 29.15 \\
$\mathrm{FeO}$ & 64.27 & 63.87 & 62.41 & 64.62 \\
$\mathrm{MgO}$ & 4.18 & 4.58 & 6.08 & 4.52 \\
$\mathrm{CaO}$ & 1.21 & 1.17 & 0.33 & 0.45 \\
$\mathrm{MnO}$ & - & - & 1.29 & 1.26 \\
\hline
\end{tabular}

Abbreviation: fayalite (Fa).

etry of fayalite crystals and show the possibility of substitutions in it of magnesium, calcium, manganese and, in a small amount, aluminuim.

\section{Iron-oxide phases}

The presence of magnetite/maghemite crystals in the studied slags was established microscopically in reflected light and byXRD analyses (Figs 12, 13). Magnetite/maghemite was observed in isometric crystals and skeletal dendritic forms. Elemental microanalyses (SEM CDD-EDS) confirm these phases (Table 8).

The crystal-chemical formulas of the iron-oxide phases in sample $3 \mathrm{a}^{2}$ are calculated and presented below. 
Table 8

Chemical composition of iron-oxide phases in slag $3 a^{2}$ according to data from elemental microanalyses (SEM CDD-EDS)

\begin{tabular}{|c|c|c|c|c|c|c|c|c|c|}
\hline \multirow{3}{*}{$\begin{array}{l}\text { Chemical } \\
\text { elements }\end{array}$} & \multicolumn{9}{|c|}{ Content, mass \% } \\
\hline & \multicolumn{2}{|c|}{$\begin{array}{l}\text { Analysed field } 3 \mathrm{a}^{2}-1 \\
\text { (Fig. 15a) }\end{array}$} & \multicolumn{4}{|c|}{$\begin{array}{l}\text { Analysed field } \\
3 a^{2}-2 \text { (Fig. 15b) }\end{array}$} & \multicolumn{2}{|c|}{$\begin{array}{l}\text { Analysed field } 3 \mathrm{a}^{2}-4 \\
\text { (Fig. 15d) }\end{array}$} & \multirow{2}{*}{$\begin{array}{c}\begin{array}{c}\text { Analysed field } \\
3 \mathrm{a}^{2}-6 \text { (Fig. 15f) }\end{array} \\
\begin{array}{c}\text { Point } 4 \\
\text { (Mgh) }\end{array}\end{array}$} \\
\hline & $\begin{array}{l}\text { Point } 1 \\
\text { (Mag) }\end{array}$ & $\begin{array}{l}\text { Point } 2 \\
\text { (Mag) }\end{array}$ & $\begin{array}{l}\text { Point } 1 \\
\text { (Mag) }\end{array}$ & $\begin{array}{c}\text { Point } 2 \\
\text { (Mag) }\end{array}$ & $\begin{array}{l}\text { Point } 3 \\
\text { (Mag) }\end{array}$ & $\begin{array}{l}\text { Point } 4 \\
\text { (Mag) }\end{array}$ & $\begin{array}{c}\text { Point } 4 \\
\text { (Mag) }\end{array}$ & $\begin{array}{l}\text { Point } 5 \\
\text { (Mag) }\end{array}$ & \\
\hline $\mathrm{Fe}$ & 64.48 & 65.53 & 62.27 & 60.93 & 62.34 & 62.57 & 63.65 & 64.33 & 59.35 \\
\hline $\mathrm{Ti}$ & 0.81 & 0.66 & 0.79 & 0.78 & 0.72 & 0.75 & - & 0.74 & 0.59 \\
\hline $\mathrm{Al}$ & 4.71 & 4.12 & 6.39 & 7.17 & 5.93 & 6.01 & 4.85 & 4.67 & 4.20 \\
\hline $\mathrm{Mg}$ & 0.53 & 0.50 & - & 0.30 & 0.26 & 0.36 & - & - & - \\
\hline $\mathrm{Ca}$ & - & - & - & - & - & - & - & - & 0.77 \\
\hline $\mathrm{K}$ & - & - & - & - & - & - & - & - & 0.36 \\
\hline $\mathrm{Si}$ & 0.62 & 0.62 & 0.70 & 0.69 & 1.06 & 0.54 & 2.21 & 0.86 & 3.43 \\
\hline $\mathrm{O}$ & 28.84 & 28.58 & 29.86 & 30.12 & 29.67 & 29.77 & 29.29 & 29.40 & 31.29 \\
\hline
\end{tabular}

Abbreviations: magnetite (Mag), maghemite (Mgh).

In the analysed field $3 a^{2}-1$ (Fig. 15a):

- Point 1: $\left(\mathrm{Fe}_{0.96}^{+2} \mathrm{Mg}_{0.04}\right)_{1.00}\left(\mathrm{Fe}^{+3}{ }_{1.60} \mathrm{Ti}_{0.03} \mathrm{Al}_{0.38}\right.$

$\left.\mathrm{Si}_{0.04}\right)_{2.05} \mathrm{O}_{4}$ - magnetite;

- Point 2: $\left(\mathrm{Fe}^{+2}{ }_{0.95} \mathrm{Mg}_{0.05}\right)_{1.00}\left(\mathrm{Fe}^{+3}{ }_{1.67} \mathrm{Ti}_{0.03} \mathrm{Al}_{0.34}\right.$

$\left.\mathrm{Si}_{0.05}\right)_{2.09} \mathrm{O}_{4}$ - magnetite;

In the analysed field $3 a^{2}-2$ (Fig. 15b):

- Point 1: $\mathrm{Fe}^{+2}{ }_{1.00}\left(\mathrm{Fe}^{+3}{ }_{1.50} \mathrm{Ti}_{0.04} \mathrm{Al}_{0.53} \mathrm{Si}_{0.05}\right)_{2.12} \mathrm{O}_{4}-$ magnetite;

- Point 2: $\left(\mathrm{Fe}^{+2}{ }_{0.97} \mathrm{Mg}_{0.03}\right)_{1.00}\left(\mathrm{Fe}^{+3}{ }_{1.26} \mathrm{Ti}_{0.03} \mathrm{Al}_{0.55}\right.$

$\left.\mathrm{Si}_{0.05}\right)_{1.89} \mathrm{O}_{4}$ - magnetite;

- Point 3: $\left(\mathrm{Fe}^{+2}{ }_{0.98} \mathrm{Mg}_{0.02}\right)_{1.00}\left(\mathrm{Fe}^{+3}{ }_{1.43} \mathrm{Ti}_{0.03} \mathrm{Al}_{0.47}\right.$

$\left.\mathrm{Si}_{0.08}\right)_{2.01} \mathrm{O}_{4}$ - magnetite;

- Point 4: $\left(\mathrm{Fe}^{+2}{ }_{0.97} \mathrm{Mg}_{0.03}\right)_{1.00}\left(\mathrm{Fe}^{+3}{ }_{1.43} \mathrm{Ti}_{0.03} \mathrm{Al}_{0.48}\right.$

$\left.\mathrm{Si}_{0.04}\right)_{2.02} \mathrm{O}_{4}$ - magnetite.

In the analysed field $3 a^{2}-4$ (Fig. 15d):

- Point 4: $\mathrm{Fe}^{+2}{ }_{1.00}\left(\mathrm{Fe}^{+3}{ }_{1.49} \mathrm{Al}_{0.39} \mathrm{Si}_{0.17}\right)_{2.05} \mathrm{O}_{4}-$

magnetite;

- Point 5: $\mathrm{Fe}_{1.00}^{+2}\left(\mathrm{Fe}^{+3}{ }_{1.51} \mathrm{Ti}_{0.03} \mathrm{Al}_{0.38} \mathrm{Si}_{0.07}\right)_{1.99} \mathrm{O}_{4}-$ magnetite;
In the analysed field $3 a^{2}-6$ (Fig. 15f):

- Point 4: $\left(\mathrm{Fe}^{+2}{ }_{0.96} \mathrm{Ca}_{0.04}\right)_{1.00}\left(\mathrm{Fe}^{+3}{ }_{1.21} \mathrm{Ti}_{0.03} \mathrm{Al}_{0.32} \mathrm{~K}_{0.02}\right.$ $\left.\mathrm{Si}_{0.25}\right)_{1.83} \mathrm{O}_{4}$ - maghemite.

\section{Copper and residual sulfide phases in copper- containing aggregates}

Copper-containing aggregates are mainly copperiron-sulfide inclusions. In reflected light, they are observed as spherical drops. In sample $3 \mathrm{a}^{1}$ in the analysed field $3 a^{1}-2$ (Fig. 14b), relics of ore were found and, more precisely, sulfide minerals bornite and chalcopyrite with the composition given in Table 9. Point 4 in the analysed field $3 a^{1}-1$ (Fig. $14 a$, Table 9) is probably a residue of the used raw ore material with tennantite-type minerals.

Numerous sulfide inclusions and copper-containing aggregates were found in sample $3 \mathrm{a}^{2}$. They are very clearly visible in analysed fields $3 a^{2}-3$,

Table 9

Chemical composition of iron-copper sulfide phases in slag sample $3 a^{1}$ according to data from elemental microanalyses (SEM $C D D-E D S)$

\begin{tabular}{|c|c|c|c|c|c|c|c|c|}
\hline \multirow{3}{*}{$\begin{array}{l}\text { Chemical } \\
\text { elements }\end{array}$} & \multicolumn{8}{|c|}{ Content, mass \% } \\
\hline & \multicolumn{2}{|c|}{$\begin{array}{l}\text { Analysed field } 3 \mathrm{a}^{1}-1 \\
\text { (Fig. 14a) }\end{array}$} & \multicolumn{3}{|c|}{$\begin{array}{l}\text { Analysed field } 3 \mathrm{a}^{1}-2 \\
\text { (Fig.14b) }\end{array}$} & \multicolumn{3}{|c|}{$\begin{array}{l}\text { Analysed field } 3 \mathrm{a}^{1}-3 \\
\quad \text { (Fig. 14d) }\end{array}$} \\
\hline & Point 3 & Point 4 & Point 1 & Point 2 & Point 3 & Point 1 & Point 2 & Point 3 \\
\hline $\mathrm{Cu}$ & 54.32 & 21.44 & 62.76 & 65.07 & 71.00 & 55.30 & 64.53 & 64.99 \\
\hline $\mathrm{Fe}$ & 18.03 & 33.07 & 13.56 & 16.36 & 9.86 & 15.71 & 10.04 & 9.73 \\
\hline $\mathrm{S}$ & 27.64 & 17.62 & 23.68 & - & 19.14 & 21.19 & 24.30 & 24.12 \\
\hline As & - & 10.22 & - & 18.57 & - & 7.81 & 1.13 & 1.17 \\
\hline $\mathrm{Ca}$ & - & 1.61 & - & - & - & - & - & - \\
\hline Si & - & 5.20 & - & - & - & - & - & - \\
\hline $\mathrm{Al}$ & - & 1.66 & - & - & - & - & - & - \\
\hline
\end{tabular}


$3 a^{2}-4$ and $3 a^{2}-6$ (Fig. 15c, d, f). Analysed field $3 a^{2}-$ 4 contains a copper-sulfide aggregate with clearly manifested zonation (Fig. 15d). Its periphery and the central parts are with different compositions, presented below. The results of the elemental mi- croanalyses in fields $3 a^{2}-3$ (Fig. 15c) and $3 a^{2}-4$ (Fig. 15d) are presented in Table 10.

The results of the chemical study of coppercontaining aggregates from the analysed field $3 \mathrm{a}^{2}-6$ (Fig. 15f) are presented in Table 11. They have a
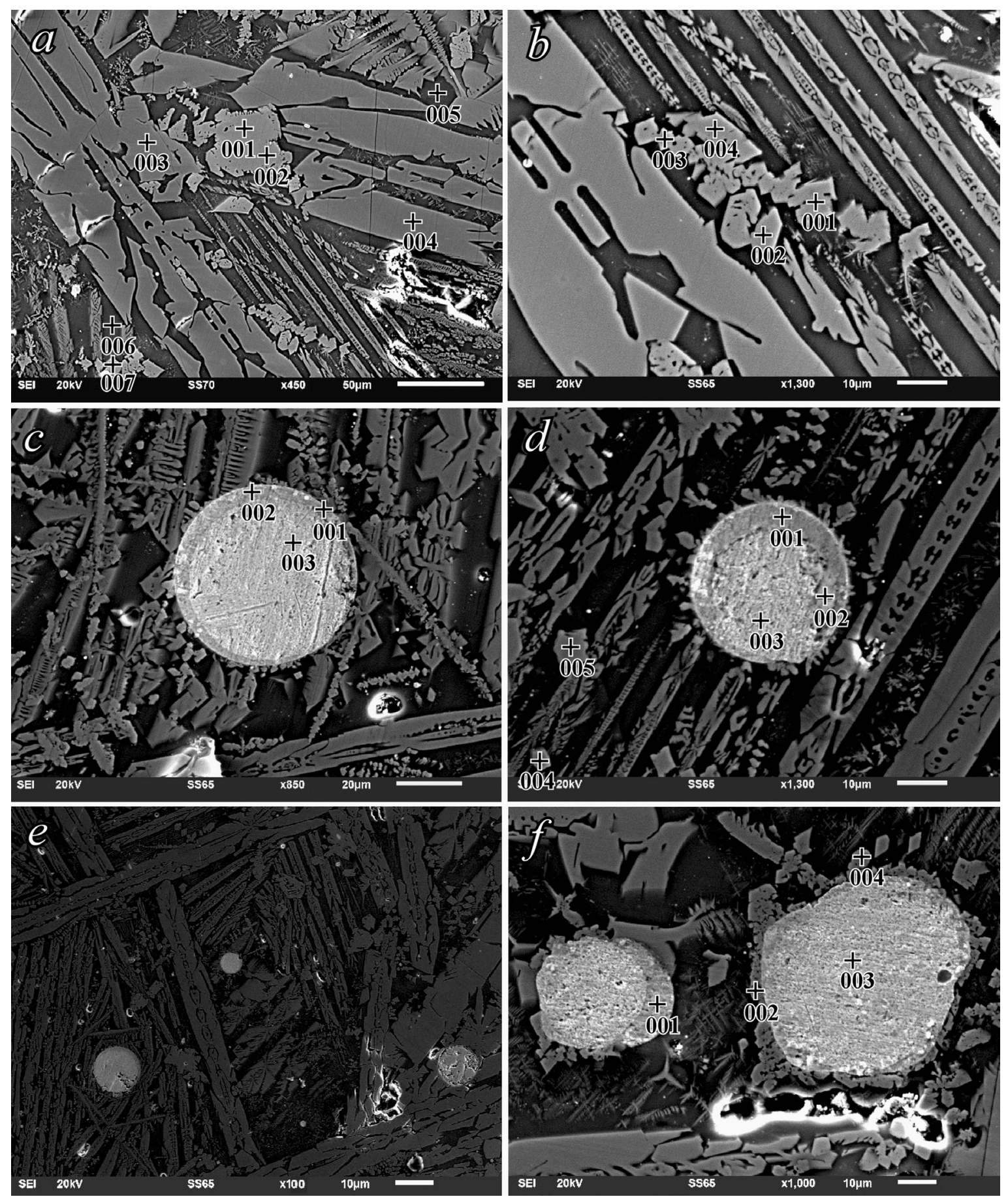

Fig. 15. Scanning electron microscope images of the phases identified in sample $3 a^{2}$ and CDD-EDS mapping of analysed points: a) analysed field $3 \mathrm{a}^{2}-1$ with points: 1, 2 (magnetite), 3, 4 (fayalite), 5, 6 (slag glass); $b$ ) analysed field $3 \mathrm{a}^{2}-2$ with points 1 , 2, 3 and 4 (magnetite); $c$ ) analysed field $3 \mathrm{a}^{2}-3$ with points $1,2,3$ (copper-containing aggregates); $d$ ) analysed field $3 \mathrm{a}^{2}-4$ with points 1 , 2, 3 (aggregates), 4 and 5 (magnetite); $e$ ) microstructure of the slag from sample $3 \mathrm{a}^{2} ; f$ ) analysed field $3 \mathrm{a}^{2}-6$ with points 1 , 2, 3 (aggregates) and 4 (maghemite). 
Table 10

Chemical composition of copper-containing aggregates in slag sample $3 a^{2}$ according to data from elemental microanalyses (SEM CDD-EDS)

\begin{tabular}{|c|c|c|c|c|c|c|}
\hline \multirow{3}{*}{$\begin{array}{l}\text { Chemical } \\
\text { elements }\end{array}$} & \multicolumn{6}{|c|}{ Content, mass \% } \\
\hline & \multicolumn{3}{|c|}{ Analysed field $3 a^{2}-3$ (Fig. 15c) } & \multicolumn{3}{|c|}{ Analysed field 3a²-4 (Fig. 15d) } \\
\hline & Point 1 & Point 2 & Point 3 & Point 1 & Point 2 & Point 3 \\
\hline $\mathrm{Cu}$ & 79.47 & 80.66 & 97.12 & 80.90 & 87.78 & 93.96 \\
\hline $\mathrm{Fe}$ & 3.62 & 2.70 & - & 2.34 & 2.23 & 1.70 \\
\hline $\mathrm{S}$ & 16.29 & 16.63 & - & 16.76 & 16.63 & - \\
\hline $\mathrm{O}$ & - & - & 2.98 & - & 9.99 & 4.34 \\
\hline
\end{tabular}

chemical zonation and a very heterogeneous composition at different points. Some of these aggregates have high sulfur content in their periphery (Fig. 15f, Table 11 - point 1 ). The periphery of other aggregates consists of copper-iron oxide without sulfur, and with impurities of Si, $\mathrm{Al}$ and $\mathrm{Ca}$ (Fig. 15f, Table 11 - point 2). The central parts of the units are made of almost pure copper (Fig. 15f, Table 11 - point 3).

\section{Slag glass}

During the cooling of molten copper-containing raw materials, the main crystal phases in the slag crystallize from the melt. The residual mass is a multicomponent, optically isotropic, amorphous phase, referred to as slag glass. The chemical composition of the slag glass in all studied samples was analysed by spot analyses. The results are presented in Table 12.
Table 11

Chemical composition of copper-containing aggregates with zonal structure in slag sample $3 a^{2}$ according to data from elemental microanalyses (SEM CDD-EDS)

\begin{tabular}{cccc}
\hline \multirow{2}{*}{$\begin{array}{c}\text { Chemical } \\
\text { elements }\end{array}$} & \multicolumn{3}{c}{ Content, mass \% } \\
\cline { 2 - 4 } & Point 1 & Point 2 & Point 3 \\
\hline Cu & 75.86 & 16.55 & 97.66 \\
$\mathrm{Fe}$ & 3.68 & 48.67 & - \\
$\mathrm{S}$ & 17.97 & - & - \\
$\mathrm{Ca}$ & - & 0.44 & - \\
$\mathrm{Al}$ & - & 4.31 & - \\
$\mathrm{Si}$ & - & 2.39 & - \\
$\mathrm{O}$ & 2.49 & 27.67 & 2.34 \\
\hline
\end{tabular}

Table 12

Chemical composition of the slag glass in the studied samples from the area of the village of Krushevets according to data from elemental microanalyses (SEM CDD-EDS)

\begin{tabular}{|c|c|c|c|c|c|c|c|c|c|c|c|}
\hline \multirow{3}{*}{ Oxides } & \multicolumn{11}{|c|}{ Content, mass \% } \\
\hline & \multicolumn{2}{|c|}{$\begin{array}{c}\text { Analysed field } \\
1 a^{1}-1 \\
\text { (Fig. 6a) }\end{array}$} & \multicolumn{2}{|c|}{$\begin{array}{c}\text { Analysed field } \\
1 \mathrm{a}^{1}-2 \\
\text { (Fig. } 6 b)\end{array}$} & \multicolumn{2}{|c|}{$\begin{array}{c}\text { Analysed field } \\
2-1 \\
\text { (Fig. 10b) }\end{array}$} & \multirow{2}{*}{$\begin{array}{c}\begin{array}{c}\text { Analysed field } \\
2-5 \\
\text { (Fig. 10f) }\end{array} \\
\text { Point } 7\end{array}$} & \multicolumn{2}{|c|}{$\begin{array}{c}\text { Analysed field } \\
3 a^{1}-1 \\
\text { (Fig. 14a) }\end{array}$} & \multicolumn{2}{|c|}{$\begin{array}{c}\text { Analysed field } \\
3 \mathrm{a}^{2}-1 \\
\text { (Fig. 15a) }\end{array}$} \\
\hline & Point 4 & Point 5 & Point 9 & Point 10 & Point 2 & Point 3 & & Point 5 & Point 6 & Point 5 & Point 6 \\
\hline $\mathrm{SiO}_{2}$ & 46.51 & 47.50 & 48.74 & 48.78 & 54.13 & 54.60 & 56.45 & 53.45 & 54.20 & 42.88 & 41.74 \\
\hline $\mathrm{TiO}_{2}$ & 0.59 & 0.58 & - & 0.64 & - & - & - & - & - & - & - \\
\hline $\mathrm{Al}_{2} \mathrm{O}_{3}$ & 13.18 & 13.45 & 14.87 & 14.48 & 10.96 & 10.98 & 11.65 & 11.45 & 11.61 & 16.41 & 11.92 \\
\hline $\mathrm{FeO}$ & 26.63 & 24.46 & 20.07 & 20.82 & 20.36 & 20.22 & 17.97 & 18.14 & 17.52 & 31.84 & 36.89 \\
\hline $\mathrm{CaO}$ & 9.16 & 10.71 & 11.79 & 11.99 & 11.89 & 11.53 & 11.30 & 13.46 & 13.35 & 6.38 & 5.73 \\
\hline $\mathrm{MgO}$ & 0.50 & - & 0.26 & 0.32 & - & - & - & - & - & - & 0.29 \\
\hline $\mathrm{MnO}$ & 0.84 & 0.82 & 0.68 & 0.70 & - & - & - & - & - & - & 0.74 \\
\hline $\mathrm{K}_{2} \mathrm{O}$ & 1.87 & 1.57 & 1.58 & 1.55 & 2.66 & 2.68 & 2.61 & 2.13 & 2.18 & 2.48 & 2.23 \\
\hline $\mathrm{Na}_{2} \mathrm{O}$ & 0.72 & 0.91 & 0.61 & 0.72 & - & - & - & 1.36 & 1.14 & - & 0.44 \\
\hline $\mathrm{CuO}$ & - & - & 0.93 & - & - & - & - & - & - & - & - \\
\hline $\mathrm{SO}_{3}$ & - & - & 0.43 & - & - & - & - & - & - & - & - \\
\hline
\end{tabular}




\section{DISCUSSION}

The phase and chemical composition, as well as the microstructural characteristics of the studied samples from the area of the village of Krushevets, show that they are waste materials from sulfide smelting for copper extraction. Compared with slags from smelting oxidic ores, those from sulfide smelting are more abundand (Bachmann, 1982). The following phases were established with complex methods of investigation: silicate phases - fayalite-type with impurities, kirschsteinite and laihunite; pyroxenes of the augite-type and amorphous hosted glass; iron-oxide phases - magnetite and maghemite; copper-containing phases - bornite and chalcopyrite, chalcocite, copper-iron-sulfide and copper-sulfide aggregates, as well as drops of unbound pure copper. Among the minerals found in ancient, as well as in modern, slags are fayalite, kirschsteinite, pyroxene, magnetite and maghemite (Ivanov et al., 1967; Mihailova and Mehandrejiev, 2010; Stavrakeva and Stoytseva, 1966).

The copper content in the studied slags goes up to $1.07 \%$ (Table 1 ), indicating low process efficiency. It was presented in the form of either metallic droplets, non-stoichiometric copper oxides or sulfides, the latter being practically insoluble in the silicates. The presence of ore relics of sulfide minerals (bornite and chalcopyrite) and copper-containing aggregates (Tables 4, 6, 9-11) indicates that the heat treatment of the material did not reach the required temperature for complete melting of the ore used and complete extraction of copper.

The copper-containing ore raw materials used were probably of two main types. Samples $1 \mathrm{a}\left(1 \mathrm{a}^{1}\right.$ and $1 \mathrm{a}^{2}$ ), 2 and $3 \mathrm{a}^{2}$ (Table 1) have approximately the same composition: $\mathrm{SiO}_{2}(37.79-42.28 \%) ; \mathrm{Fe}_{2} \mathrm{O}_{3}$ (40.11-41.58\%); $\mathrm{CaO}$ (5.56-6.51\%) and $\mathrm{CuO}$ (0.41-0.74\%). In sample $3 \mathrm{a}^{1}$, the content of $\mathrm{SiO}_{2}$ is lower (29.32\%) and $\mathrm{Fe}_{2} \mathrm{O}_{3}$ is higher (54.57\%) compared to the other three samples. Sample $3 \mathrm{a}^{1}$ also has a higher $\mathrm{Cu}$ content (1.07\%).

The amount of slag glass phase in the samples depends on the chemical composition of the heattreated materials and the thermal regime - maximum melting temperature and cooling rate of the melt. Thus, in the studied slags, it was found that the glass phase in sample 2 is in smaller amount compared to the other slag samples. It is likely that this slag was obtained by heat treatment at lower temperatures, due to which more ore relics, such as bornite, chalcopyrite and copper-containing aggregates, were found in sample 2. Probably, the starting ore material in sample 2 was more difficult to melt than the other samples, judging by their chemical compositions. It was found that the composition of slag 2 has a higher content of $\mathrm{SiO}_{2}(42.28 \%)$ (Table 1).

The ore used was included in host rocks containing quartz and potassium feldspar minerals. Proof of this is the constant presence of $\mathrm{CaO}$ in 10 of 11 analysed points (9.16-13.46\%) with the exception of sample $3 \mathrm{a}^{2}-1$ (Table 12). This assumption is also supported by the presence of $\mathrm{K}_{2} \mathrm{O}$ and $\mathrm{Al}_{2} \mathrm{O}_{3}$ in the slag glass. The composition of fayalite shows that the used ore raw material contained manganese-, calcium-, magnesiumand aluminium-containing minerals (Tables 2, 3, 7).

The slag samples from the area of the village of Krushevets are very similar in their characteristics to the previously studied slags found in the archaeological sites in the areas of Propadnala Voda, Koru Cheshme, Rosen and Atiya (Stavrakeva and Tzankova, 2016b; Tzankova et al., 2016).

\section{CONCLUSION}

The archaeological metallurgical slags provide valuable information about the material culture, mining and metal extracting skills of the local population. The mineral composition of the slags, as well as their structural and phase characteristics, allow us to claim that, in the studied area, in the past there was copper metallurgical activity based on copper sulfide mining. The phase composition of the slags shows that the population of this region melted sulfide ore with different additive content. While the origin of the ore could not be determined, it may be related to the copper-sulfide ore deposits in the region.

\section{Acknowledgements}

The authors sincerely thank two anonimous reviewers for their comments and suggestions. This research was conducted under the project NSF K02/6/12.12.2014. We are grateful to all members of the project team who assisted in finding and locating ancient metallurgical slags.

\section{REFERENCES}

Bachmann, H.-G. 1982. The identification of slags from archaeological sites. University College London, Instute of Archaeology Publications 28 (6), 80 pp., https://doi. org/10.4324/9781315418216.
Bogdanov, B. 1987. The copper ore deposits in Bulgaria. Technika, Sofia, 388 pp. (in Bulgarian).

Dabovski, H. 2009. Upper Cretaceous geology. Introduction. In: Zagorchev, I., Dabovski, H., Nikolov, T. (Eds), Geology 
of Bulgaria. Vol. II. Mesozoic geology. "Prof. M. Drinov" Academic Press, Sofia, 305-307 (in Bulgarian, with English abstract).

Georgiev, G.K. 1987. Mineral Resources from the time of the Thracians. Bulgarian Academy of Sciences, Sofia, 133 pp. (in Bulgarian).

Hristov, N., Nachev, I., Nedev, D. 1953. Preliminary report on the detailed geological research works in the area of the villages Varshilo, Krushevets, Izvor and Zidarovo, Burgas region, in 1952. Geofund, Report I-293 (in Bulgarian).

International Centre for Diffraction Data. 1997. PCPDFWIN software, Version 1.30.

Ivanov, I., Bakardzhiev, P., Grozdanov, I. 1967. Phase composition and structure of the waste copper slags from CMP "G. Damyanov" - Pirdop. Mining and metallurgy 9, 13-17 (in Bulgarian).

Leshchakov, P., Dimitrov, K., Kunze, R. 2015. Searches of archaeological sites in the Rosen and Varlibryazhko ore fields. In: Kabakchieva, G. (Chief Ed.), Archaeological discoveries and excavations in 2014, National Archaeological Institute with Museum, Bulgarian Academy of Sciences, Sofia, 849-852 (in Bulgarian).

Mihaylov, I. 2010. Burgas copper mines. History of mining in Strandzha. Adular - Ivan Mihailov, Burgas, 187 pp. (in Bulgarian).

Mihailova, I. 2009. Investigation of the phase composition and structure of furnace metallurgical slags from copper production. Annual of the University of Mining and Geology 52, 73-78 (in Bulgarian, with English abstract).

Mihailova I., Mehandrejiev, D. 2010. Characterization of fayalite from copper slags. Journal of the University of Chemical Technology and Metallurgy 45, 317-326.
Milev, V., Stanev, V., Ivanov, V. 1996. The ores mined in Bulgaria 1878-1995. Statistical reference book. Zemia-93 Press, Sofia, 196 pp. (in Bulgarian).

Newbury, D.E., Ritchie, N.W.M. 2013. Is scanning electron microscopy/energy dispersive X-ray spectrometry (SEM/ EDS) quantitative?. Scanning 35, 141-168.

Schlesinger, M.E., King, M.J., Sole, K.C., Davenport, W.G. 2011. Extractive Metallurgy of Copper, $5^{\text {th }}$ edition. Elsevier, Oxford, $472 \mathrm{pp}$.

Stavrakeva, D. 1990. Method for calculation of the valence of transitional elements in the composition of crystal phases. Comptes rendus de l'Académie bulgare des Sciences 43 (11), 57-60.

Stavrakeva D., Tzankova, N. 2016a. Chemico-mineralogical characterization of ancient slags from Rosen Ore Field. Part 1 - Propadnala voda deposit. Annual of the University of Mining and Geology 59 (1), 55-60 (in Bulgarian, with English abstract).

Stavrakeva D., Tzankova, N. 2016b. Ancient metallurgical slags from the Rossen Ore Region - a potential raw material for the production of copper and lanthanides. Geology and mineral resources 6, 36-40 (in Bulgarian, with English abstract).

Stavrakeva, D., Stoytseva, R. 1966. Chemical-petrographic characteristics of the waste slags from SMME "G. Dimitrov", Eliseyna station. Mining and metallurgy, scroll metallurgy 2, 15-18 (in Bulgarian).

Tzankova N., Stavrakeva, D., Leshtakov, P., Dimitrov, K. 2016. Chemico-mineralogical characterization of ancient slags from Rosen Ore Field. Part 2 - Korucheshme and Rosen deposits, metallurgical center "Atiya". Annual of the University of Mining and Geology 59 (1), 61-66 (in Bulgarian, with English abstract). 